\title{
Houses of History and Homepages: Museums of Communism in Eastern and Central Europe and their Online Presence
}

\author{
Alexandra Day Coffman \\ West Virginia University
}

Follow this and additional works at: https://researchrepository.wvu.edu/etd

\section{Recommended Citation \\ Coffman, Alexandra Day, "Houses of History and Homepages: Museums of Communism in Eastern and Central Europe and their Online Presence" (2013). Graduate Theses, Dissertations, and Problem Reports. 514. \\ https://researchrepository.wvu.edu/etd/514}

This Thesis is protected by copyright and/or related rights. It has been brought to you by the The Research Repository @ WVU with permission from the rights-holder(s). You are free to use this Thesis in any way that is permitted by the copyright and related rights legislation that applies to your use. For other uses you must obtain permission from the rights-holder(s) directly, unless additional rights are indicated by a Creative Commons license in the record and/ or on the work itself. This Thesis has been accepted for inclusion in WVU Graduate Theses, Dissertations, and Problem Reports collection by an authorized administrator of The Research Repository @ WVU. For more information, please contact researchrepository@mail.wvu.edu. 


\title{
Houses of History and Homepages: Museums of Communism in Eastern and Central Europe and their Online Presence
}

\author{
Alexandra Day Coffman \\ A thesis submitted to the Eberly College of Arts and Sciences \\ at West Virginia University in partial fulfillment of the requirements \\ for the degree of
}

\author{
Master of Arts \\ in \\ History
}

\author{
Committee: \\ Robert Blobaum, Ph.D. \\ Katherine Aaslestad, Ph.D. \\ Melissa Bingmann, Ph D. \\ Department of History
}

Morgantown, West Virginia

2013

Keywords: Central and Eastern Europe; Communism; Museum Websites 


\begin{abstract}
Houses of History and Homepages: Museums of Communism in Eastern and Central Europe and their Online Presence
\end{abstract}

\author{
Alexandra Day Coffman
}

Museums of communism have been appearing all over Central and Eastern Europe, as has the interest in them. Memorabilia sells well and tourists are interested in what life was like behind the Iron Curtain. If these museums show how they present, represent, and deal with the recent past, museum websites also give insight into the museums' greater outreach. Communism is portrayed in several ways in different countries, but they generally depict the country as a victim of Soviet rule and influence. This study examines resources that are available for the global audience and observes how engaged the museums are in presenting their information via new media and internet websites.

Case studies of museums of communism are presented from the following museums and historical education centers: The Stasi Museum and the DDR Museum in Berlin, Germany; the Institute of National Remembrance in Warsaw, Poland; the Museum of Communism in Prague, Czech Republic; the House of Terror Museum and Memento Park in Budapest, Hungary; and the Museum of Occupations in Tallinn, Estonia. These sites of public memory can be seen as metaphors for the historic transition from communism in these respective states. How museums and online displays of history are conceptualized show, in part, how countries and their historians are dealing with the recent past, how that past is presented to the public, and how they want to portray it to the world. 


\section{Table of Contents}

Chapter One: Introduction

Chapter Two: East Germany

Chapter Three: Poland

Chapter Four: The Czech Republic

Chapter Five: Hungary 


\section{Chapter One: Introduction}

The communist museum interest has crept into the literature of the present time, including literature about a specific museum, the Museum of Communism in Prague. Slavenka Drakulić, famed Croatian author, dedicated her first chapter (and her book title) to the topic of museums of communism in her book of fables, A Guided Tour through the Museum of Communism. This book is quite insightful in pointing out what these museums are portraying, who visits them, and what they are lacking.

The first chapter, bearing the same name as the novel, is written from the perspective of a mouse named Bohumil who lives in the Prague Museum of Communism. In this particular fable, Bohumil points out the brief, cheap history books for sale that cannot possibly tell the whole story. ${ }^{1}$ Drakulić writes "...Communism is not so much about exhibits, [as] about seeing. It is more about how one lived in those times, or more to the point, how one survived them.." She talks about the invisible parts of communism, the "shades of gray" in everyday life. ${ }^{3}$ The mouse, through Drakulić's writing, shows frustration at simply putting old communist goods on display without expressing to the visitor the experience of living, of what it was like to actually live during communist times.

Drakulić writes about the "innocent visitor" who has never experienced communism, because those who have lived through it do not visit the museum. ${ }^{4}$ She pointedly writes that Milena, the elderly cleaning woman, is actually the best "exhibit"

\footnotetext{
${ }^{1}$ Slavenka Drakulić, A Guided Tour through the Museum of Communism, (New York: Penguin, 2011 ), 4.

2 lbid, 6.

3 lbid, 8.

4 lbid, 6.
} 
but no visitors ever ask her about her life experience under communism. ${ }^{5}$ Drakulić gives a balanced opinion about the lack of personal history in the museum, but Bohumil replies that "maybe the absence of individual stories is the best illustration of the fact that individualism was the biggest sin one could commit."

She also subtly suggests that the overrepresentation of the USSR and underrepresentation of the Czechoslovak Communist Party imply that Czech citizens (as in many of the non-USSR countries) see themselves as victims of Communism and not the "original sinners." Instances such as the prominent documentation and display of the 1968 rebellion but the museum's failure to mention that 40 percent of the population voted for the Communists in the 1946 election show her point. ${ }^{8}$

Despite the drawbacks, the flaws, and the unseen history of these museums, Drakulić writes that "the importance of it is that it exists." The museum can exist because communism and Soviet influence are in the past.

\section{New Media and Globalization in Museums}

With one web search of tourist sites in Eastern or Central Europe, a person will immediately spot several museums of Communism or post-communist commemoration. It is hard to ignore the presence of everything from state museums to locally-owned bars that sport communist-era memorabilia and tell the visitor about the experience of living "behind the Iron Curtain." Along with the popularity of a newly-accessible

\footnotetext{
${ }^{5}$ lbid, 6.

${ }^{6} \mathrm{lbid}, 9$.

7 Ibid, 13.

${ }^{8} \mathrm{lbid}, 13$.

${ }^{9}$ lbid, 25.
} 
communist history, there has been a worldwide museum boom in the last three decades. $^{10}$

The European Union has taken a strong interest in national museums and the prospect of a Europe-wide "House of History." The dissemination of history via museums is a very important part of dealing with the past, the present, and hopes of the future for any society. No longer are museums just places for a straight-forward chronicle of objects and images; museums around Europe now are places for dialogue that can lead to healing and reconciliation among citizens of the same or even different countries. ${ }^{11}$ Peter Aronsson, one of the many contributors to the European National Museums conference in 2012, writes that "great hopes are being expressed for [museums'] ability to create cohesion and community, creativity, and tolerance."12 On top of the more idealistic notions of art and community, museums also bring jobs and tourism as well as the most basic function of serving as a secure place where the nations' historic treasures are kept.

Museums rank high on the policy agenda these days. ${ }^{13}$ The EU has shown its support by creating the project European National Museums: Identity Politics, the Uses of the Past and the European Citizen (EuNaMus) that is working toward a showcase for the vast diversity in Europe as well as a more comprehensive scholarship on national

\footnotetext{
${ }^{10}$ Randolph Starn, "A Historian's Brief Guide to New Museum Studies," The American Historical Review, 110 (February 2005): 96, accessed March 30, 2013.

${ }_{11}$ Bodil Axelsson, Christine Dupont, and Chantal Kesteloot, eds., "Entering Two Minefields: Research for PolicyMaking and the Creation of New History Museums in Europe." Conference Proceedings from EuNaMus, European National Museums: Identity Politics, the Uses of the Past, and the European Citizen. Brussels, (25 January 2012), EuNaMus Report No. 9, Linköping University Electronic Press. http://www.ep.liu.se/ecp/083/ecp12083.pdf , 10.

${ }_{12}$ Peter Aronsson, "Reflections on Policy Relevance and Research in EuNaMus," 26.

${ }^{13}$ Ibid, 26.
} 
museums and their complexities. ${ }^{14}$ Even at a time of economic crisis, the EU considers the research, scholarship, and construction of museums and "houses of history" to be very important to the development of a more culturally-rich and informed Europe.

Although Eastern and Central Europe are rapidly adapting to the major transformations resulting from regime change in the late 1980s and into the 1990s, Klaus Müller (an international museum consultant) writes, "the long term effects of Communist rule still exist as a shared past and a burden." ${ }^{15}$ Many decades of suppressed creativity, state-funded art, and cultural infrastructures that were subsidized and promoted by the State undermined the majority of autonomous and cultural initiatives. ${ }^{16}$ Unlike the West, these museum curators, historians, and consultants had little experience with freedom of expression and even more importantly with creating and maintaining an institution without state-funding or guidance. Thus, new generations as well as re-trained older ones have begun the process of creating memorials and places of historical display while also learning to use the new media and technology that are available.

The use of new media in the presentation and discussion of history has been a slow process, but has been a growing focus for many groups and institutions. For example, the Roy Rosenzweig Center for History and New Media based at George

\footnotetext{
14 "Research," European National Museums, accessed March 18, 2013, http://www.eunamus.eu/research/researchresearch.html.

${ }^{15}$ Klaus Müller, "'Speaking English': A Dialogue with Eastern and Central European Museum Professionals," Curator: The Museum Journal, 48 (January 2005):59, accessed April 1, 2013. http://ad4tq3gq5x.search.serialssolutions.com/?ctx_ver=Z39.88-2004\&ctx_enc=info\%3Aofi\%2Fenc\%3AUTF-

8\&rfr_id=info:sid/summon.serialssolutions.com\&rft_val_fmt=info:ofi/fmt:kev:mtx:journal\&rft.genre=article\&rft.atitle=\%E $2 \% 80 \% 9$ CSpeaking+English $\%$ E2\% $80 \% 9 \mathrm{D} \% 3 \mathrm{~A}+\mathrm{A}+$ Dialogue+with+Eastern+and+Central+European+Museum+Profe ssionals\&rft.jtitle=Curator\%3A+The+Museum+Journal\&rft.au=M\%C3\%BCller\%2C+Klaus\&rft.date=2005-01$01 \&$ rft.issn $=0011-3069 \&$ rft.eissn $=2151$ 6952\&rft.volume=48\&rft.issue $=1 \&$ rft.spage $=57 \&$ rft.epage $=73 \&$ rft_id=info:doi $/ 10.1111 \% 2 F j .2151$ 6952.2005.tb00154.x\&rft.externalDBID=n\%2Fa\&rft.externalDocID $=10 \_1111 \_j \_151 \_6952 \_2005 \_t b 00154 \_x$. ${ }^{16}$ Ibid, 59.
} 
Mason University has used digital technology and new media to "democratize history— to incorporate multiple voices, reach diverse audiences, and encourage popular participation in presenting and preserving the past." ${ }^{17}$ Museums and educational centers that engage with new media can reach many more people and use their voices in telling the history of places and events. With global input, the Center for History and New Media is able to launch sites such as "Making the History of 1989." This site offers students, teachers, and scholars access to "hundreds of primary sources on or related to the events of 1989 and the end of the Cold War in Europe, interviews with prominent historians, and a series of resources for teachers at both the high school and college level."18

New technology and online media have changed the development and implementation of many fields, including public history. Randolph Starn, a historian, writes that new museum visitors have different expectations for museums and have the inclination

to reject traditional, low tech, interpretative technologies that employ academic jargon with which they have no familiarity; its preference for new information technologies, with which many people feel comfortable and in control...;its greater interest in behind-the-scenes technical operations; its demand for noncollections-based facilities and services... ${ }^{19}$

New media is a huge part of the current culture and museum visitors want to use it in all aspects of life. Having a good platform of interaction, be it online exhibits or an

\footnotetext{
17 "About," Roy Rosenzweig Center for History and New Media, accessed April 2, 2013, http://chnm.gmu.edu/about/. 18 "Making the History of 1989 Site Launches." Roy Rosenzweig Center for History and New Media, accessed April 1, 2013, http://chnm.gmu.edu/news/making-the-history-of-1989-site-launches/.

${ }^{19}$ Starn, "A Historian's Brief Guide to New Museum Studies," 95.
} 
informative and interactive website, is an important part of being relevant in the $21^{\text {st }}$ century.

Museums often implement new media approaches and use them on their institutions' websites. In the following case studies there is a wide spectrum of the use of new media. Some museums, such as the DDR Museum, offer several on-line exhibits featured on the Google Cultural Institute site, whereas some museums' websites offer little more than the hours of operation and maps to the building. Most museums of communism fall somewhere in-between.

\section{Previous Research}

There is a vast interest among historians and journalists to write about postcommunist development, including the new museums that have been established in Central and Eastern Europe. As the European National Museums research has found, national museums in Eastern and Central Europe have typically been researched as case studies. ${ }^{20}$ This is mainly the case because the experience of communism and Soviet influence in each Eastern and Central European country was quite different, including the way in which each museum or center for remembrance came to be. Most are built around the notion of victimization of their countries by Soviet rule or domination, externalizing the regime and not accepting it, in part, as their own doing. The EuNaMus is working to "develop a body of knowledge and expertise on the historical trajectories and contemporary complexity of national museums." ${ }^{21}$ There are many facets to this body of knowledge that have not been explored, or are difficult to

\footnotetext{
${ }^{20}$ Research," European National Museums. http://www.eunamus.eu/research/research-research.html. ${ }^{21}$ Ibid.
} 
keep current, such as virtual exhibits and online databases. Websites and online exhibits are also parts of public history that are constantly changing and should be continually updated as an important part of engaging the public in historical material and education.

\section{Methodology}

In this thesis, I will present case studies of museums from former East Germany, Poland, the Czech Republic (former Czechoslovakia), Hungary, and Estonia (formerly part of the USSR). These countries all experienced communist rule whether under their countries' own parties or as a part of the Soviet Union; they had different relationships to the USSR. Each country has responded to public memory and museums in a different way. Some sites presented here are privately-owned and operated whereas others are state-run. Some museums and memory centers were opened as soon as the communist state crumbled, whereas others did not open for nearly a decade.

As the communist influence in Eastern Europe crumbled, the technology of the World Wide Web emerged. In 1989, the Berlin Wall came crashing down, the same year the World Wide Web was proposed as an information system and dial-up internet was first offered to the public. ${ }^{22}$ The popularity of internet access continued to grow and so did the use of the web as a means for communicating faster and to broader audiences. It was not long before businesses and organizations were putting their information on the web to draw in more customers and visitors. Initially, a website for an organization served as little more than a virtual flyer; however, with the quick advances of the web,

\footnotetext{
${ }^{22}$ Alice Gribbin, “A Brief History of the Internet,” New Statesman (Aug 15, 2011): 30, accessed March 3, 2013, http://search.proquest.com/docview/920812193?accountid=2837.
} 
less than three decades later, people from around the world can take virtual tours of museums, access archival documents, and even view museums that exist only in a virtual form. Some museums have taken advantage of these superb teaching and outreach tools, others have seriously lagged behind. This has to do with everything from funding and priority of a given government to the nature of the audience.

The technology for online access and virtual interaction is not the only recent development relevant to this study. The historicizing of communism and Soviet hegemony is also very recent. Many people who lived in the Soviet bloc are still alive and can weigh in on the history of these topics. Attitudes are shaped by the communities and countries that actually experienced this history. In some regards this has made the establishment of a museum easier, such as the Museum of Communism in the Czech Republic where artifacts were purchased from rummage sales. However, it presents many challenges as well. Decisions about matters ranging from word choice to where museums are located must be made so as not to upset or offend anyone still living who experienced these situations. One can look to the Enola Gay controversy in the United States to see that history has many sides, and telling a difficult story with survivors or relatives still living discourages a real discourse. The museums of communism will continue to change as the events recede farther into the past and societies look back more objectively on that past. For example, many states will be able to more openly discuss those citizens who were part of the Secret Police once those citizens are no longer living. The society will also not feel as personally touched by the opening of police files and can look at them more analytically. 
In a world where globalization and new media are so important that they are topics of entire university courses, it is important to explore how museums are using these important tools of outreach. This not only reflects on the museums' overall ability to stay relevant but severely limits the audiences they could reach if not applied correctly. The EuNaMus posits the main research question: "How do national museums interact with historical and contemporary globalizing forces?"23 The international access to museum websites--and sometimes archives_has allowed millions of people more access than ever before to historical interpretation and narrative. The wider access to this information, coming from the direct source, helps to form a picture of the past (be it accurate or biased), and allows the viewer to question the present. These resources can help people understand the common struggle that citizens shared under communism, which led to many of the revolutions and changes of the system.

Virtual museums are becoming more frequently used as new media are discovered by historians and museum curators looking for another outlet that reaches a wider audience, especially a young one. The younger generation has grown up in a visual media and technological world and is much more comfortable finding information on the internet than through other media. Virtual museums can be casually surfed from a smartphone instead of an entire day trip to a museum. Many virtual museums and virtual exhibitions have their roots in web sites maintained by museums so they are most often used as extensions of current museums. Virtual museums are appealing to both young people and public historians because of their easy access, loose structure, hyper-linking capacity, interactivity, and multimedia capabilities.

\footnotetext{
${ }^{23}$ Octavi Quintana-Trias, "Welcome Address," in Entering the Minefields, 19.
} 
In the following chapters, I will first introduce the museums: The Stasi Museum and the DDR Museum in Berlin, Germany; the Institute of National Remembrance in Warsaw, Poland; the Museum of Communism in Prague, Czech Republic; the House of Terror Museum and Memento Park in Budapest, Hungary; and the Museum of Occupations in Tallinn, Estonia. I will then examine the English portion of the website (although observations about other language offerings will also be made). The majority of web pages offer only the native language of the country and English, so the English translation of the site shows the intention and the level of global outreach on the web. Finally, I will analyze and interpret these museums and their web presence within a comparative framework.

The museum websites have slightly different target groups: young and old demographics, native and non-native (mostly English) speakers, those uninformed about the museum's main topic and those with some knowledge about it. Websites are not universal in their quality. Depending on the museum's resources, audience, and general attention to outreach, a website may look like anything from a professional business site to a basic, homemade one. In the museums mentioned above, the websites vary tremendously, showing the level of desire to properly represent their institution to both native and international audiences.

The way countries and private citizens handle these museums and the museum outreach helps show how the countries have begun to deal with memory, history, change, governmental decisions, and how they relate with their own citizens as well as the wider world. The construction of a statue park does not just show that Budapest wants another tourist attraction, it shows that citizens want to preserve their history- 
good or bad-while keeping it out of everyday life. The highly interactive DDR Museum website shows the commitment not only to commemorate and address East Germany's communist past, but also to make sure the history is understandable and accessible to as many people as possible. Museums have long been a way to show a country's past and now, with new media, a museum can have a longer reach and hopefully bring in more voices that promote dialogues about history among global citizens. 


\section{Chapter Two: East Germany}

East Germany (The Deutsche Demokratische Republik or DDR) was perhaps one of the most recognized countries under Soviet influence due to the very symbolic Berlin Wall that was placed between East and West Berlin. One city, split down the middle exemplified the division of the East and West worlds. The country was established in 1949 and reunified with West Germany in 1990. East Germany also had the infamous Stasi, the secret police apparatus that employed thousands of full-time employees and a hundred thousand unofficial informers (inoffizielle Mitarbeiter) that maintained secret files on the majority of East German citizens. ${ }^{24}$

Michael Gehler in Three Germanies summaries the history of $20^{\text {th }}$ century Germany into a brief statement: "The Weimar Republic was a democracy without democrats; the Federal Republic a democracy of those who were growing to be and gradually became convinced democrats; while the GDR remained a state of democrats who were prevented from practicing democracy, repressed, and persecuted." ${ }^{25} \mathrm{He}$ goes on to write "if the old Federal Republic stood for happiness, development and selffulfillment, then the GDR stood for fate, restriction, and coercion." ${ }^{26}$ The high level of state security and limited material goods made for an uncomfortable life for many of its inhabitants for its forty years of existence.

East Germany was a Central European country that was brought into the West very quickly with the reunification of Germany in 1990. The leverage of the already established West Germany helped the transition as the country began the process of

\footnotetext{
${ }^{24}$ Michael Gehler, Three Germanies: West Germany, East Germany, and The Berlin Republic, trans. Anthony Mathews (London: Reaktion Books, 2011), 216.

25 lbid, 300.

26 lbid, 301.
} 
becoming westernized as well as remembering and addressing the communist past through memorials, monuments, and museums.

It is a popular fad to remember East Germany, and much of communism, by the material things (or lack of material things) that differed from what was available in the West. Many movies, displays, and museums prefer to show Trabants and paintings of Lenin as history. But, as Charity Schribner writes, that is only part of the memory:

For it is not the securing of the material world that activates remembrance, but rather our collective displacement and reassessment of these things. It is the public's task to enact this-to shift from material to memory, from collective to collection, from site to sight. ${ }^{27}$

This shift—from material to memory and collective to collection—can only happen once society and historians can take a step back from the recent past to interpret and access what has happened and what should be used in the interpretation and remembrance of the past.

These museums work to show the story behind the artifacts or files. The Stasi Museum shows one distinct part of the DDR communist state and educates the public while helping former citizens put their files into historical as well as personal perspective. The DDR museum tries to show daily life through its material culture, but also works to show what life was like beyond flimsy cars and portraits of leaders.

\section{The Stasi Files and Museum, Berlin}

The Ministerium für Staatssicherheit (MfS) or "Stasi," the state security apparatus for East Germany, has certainly been one of the most researched topics of the Cold-

${ }^{27}$ Charity Schribner, Requiem for Communism (Cambridge: The MIT Press, 2003), 43. 
War/ communist era. From popular books such as The File by Timothy Garton Ash or the Oscar award-winning film "Das Leben der Anderen (The Lives of Others)," much attention has been given to this secret police organization. Hundreds of articles have been written on the topic and it continues to attract the interest of many historians.

East Germany was certainly a special case when it came to sheer volume of informants and workers. Garton Ash writes that "no dictatorship in modern history has had such an extensive and fanatically thorough secret police as East Germany did." ${ }^{28}$ The Stasi had approximately 125,000 full-time employees and 100,000 informants. ${ }^{29}$ Joachim Gauck, first head of the commission that oversaw the opening of the police files, writes that "the Stasi [was] the prime instrument of oppression." ${ }^{30}$ This massive amount of workers and informers left behind a paper trail over one hundred miles long. ${ }^{31}$

The question was then, what to do with all this information? Nearly twenty percent of the files were destroyed during the period of change, when the future of the files and people in them were uncertain. ${ }^{32}$ However, after both the Nazi and Communist dictatorships, the German public felt that it was important to be "open [and] self-critical" about the past. ${ }^{33}$ While all post-communist countries had to make a painful transition after the collapse of the regimes, East Germany had historic and social transitions coming from all sides. Dueck writes that East Germany "had to cope with a new, Western perspective on Nazism and the Holocaust, the oppression of the government in

\footnotetext{
${ }^{28}$ Timothy Garton Ash, The File: A Personal History (New York: Vintage Books, 1998), 21.

${ }^{29}$ Molly Andrews, "One Hundred Miles of Lives: The Stasi Files as a People's History of East Germany," Oral History 26 (1: Talking and Writing) (Spring 1998), 24, accessed February 4, 2013, http://www.jstor.org/stable/40179468.

30 Joachim Gauck and Martin Fry, "Dealing With a Stasi Past," Daedalus 123 (1: Germany in Transition) (Winter 1994), 280, accessed November 18, 2012, http://www.jstor.org.www.libproxy.wvu.edu/stable/20027230.

${ }^{31}$ Andrews, "One Hundred Miles of Lives," 25.

32 Ibid, 25.

${ }^{33}$ Gauck and Fry, "Dealing with the Stasi Past," 280.
} 
the DDR, and then the dramatic societal shift after 1989."34 East Germany did not get to make a transition as a separate state and society but was absorbed into a Western country that made many decisions about transparency and exposure that East Germany may not have made on its own. The files were moved to Die Behörde des

Bundesbeauftragten für die Stasi-Unterlagen (BStU) in Berlin, as well as other regional sites across Germany to be researched and opened for public perusal. ${ }^{35}$

Moving the files to their new locations left the former headquarters empty. Seeing it as a good educational opportunity and tourist destination, a museum was opened to educate Germans and tourists alike about the Ministerium für Staatssicherheit. The Stasi Museum opened July 15, 2006 when ASTAK (Antistalinistic action Berlin-Normannenstr.) took on the responsibility of starting a research and memorial institution after Zentrale Runde Tisch (The Central Round Table) decided it should be established. ${ }^{36}$ The museum stands as a memorial and proof that totalitarian regimes can be opposed, resisted, and overturned. ${ }^{37}$ The concept of the museum is shown in the title of the document "Ein Zentrum der Aufarbeitung kommunistischer Diktatur in Deutschland" (The Center of accounting for/coming to terms with the Communist Dictatorship in Germany).$^{38}$ Its mission is to provide a historical education about the recent past and how a communist dictatorship was replaced by democratic institutions. $^{39}$

\footnotetext{
${ }^{34}$ Cheryl Dueck, "The Humanization of the Stasi in Das Leben der Anderen," German Studies Review (Oct. 2009): 601, accessed April 10, 2012, http://www.jstor.org.www.libproxy.wvu.edu/stable/27668596.

35 "Home," BStU, accessed April 2, 2013, http://www.bstu.bund.de/DE/BundesbeauftragterUndBehoerde/_node.html.

36 "History," Stasimuseum Berlin, accessed March 3, 2013, http://www.stasimuseum.de/en/engeschichte.h̄tm.

37 "Haus 1 des Ministeriums für Staatssicherheit in Berlin - ein Zentrum der Aufarbeitung kommunistischer Diktatur in Deutschland," Stasimuseum Berlin, accessed May 28, 2013, http://www.stasimuseum.de/media/Konzeption.pdf.

${ }^{38}$ Ibid.

39 Ibid.
} 


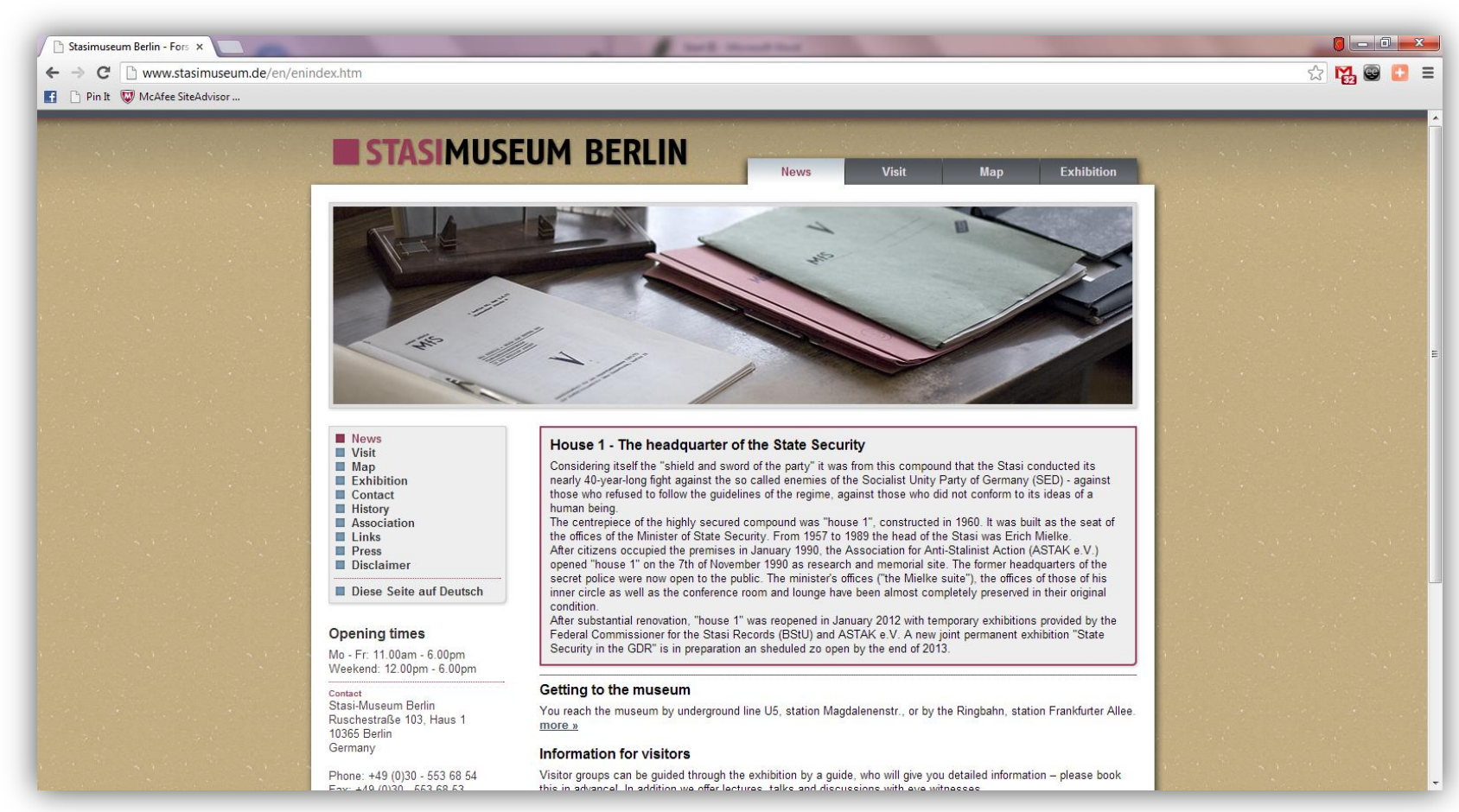

Figure 1. Screenshot of the Stasi Museum webpage. [English]. Accessed March 3, 2013. http://www.stasimuseum.de/en/enindex.htm.

This website of the Stasi Museum is easily accessible to the German or Englishspeaking visitor. The main use of this website is for tourists to find information on how to get to the museum and its operational hours. The page offers a brief history of the files and museum. It also has a short page dedicated to what the visitor might see in the museum. This includes selected photographs of different topics of the museum such as Erich Mielke's office, the general Ministry for State Security information, traditional work in the MfS, and resistance and opposition to the MfS. ${ }^{40}$

This website could easily be used by young and old, although it seems to be more targeted to a middle-aged and older audience with limited "extras" or interactive

\footnotetext{
40 "Exhibition," Stasimuseum Berlin, accessed March 3, 2013. http://www.stasimuseum.de/en/enausstellung.htm.
} 
options on the site. The information is targeted to visitors who have an idea about the history of the DDR and the Stasi. The history of the Stasi museum and files is brief and would be best understood with previous knowledge of the topic.

The website's language is essentially unbiased in the brief history of the files and museum. It mainly states dates, locations and names. The home page does refer to the Stasi's "40-year-long fight against the so-called enemies of the Socialist Unity Party of Germany (SED) - against those who refused to follow the guidelines of the regime, against those who did not conform to its ideas of a human being," but that is about as opinionated as the website gets, not portraying East Germans solely as victims but not defending the former government either. ${ }^{41}$

This website does not offer any information one could not find in the museum nor does it have much research help online. It looks very professional, but it does not offer much historical substance. It does offer a page of links about public facilities, DDR history, and German sites, which are mostly in German language only. ${ }^{42}$ Although aesthetically pleasing, this website works as little more than an online brochure. Understandably most documents are confidential, but more information about the files and artifacts, how they are stored and filed, and other details would be of interest to anyone from a casual web peruser to a public history student.

\footnotetext{
41 "News," Stasimuseum Berlin, accessed March 3, 2013, http://www.stasimuseum.de/en/enindex.htm.

42 "Links," Stasimuseum Berlin, accessed March 3, 2013, http://www.stasimuseum.de/en/enlinks.htm.
} 


\section{DDR Museum, Berlin}

While most museums are dedicated to specific or outstanding events in the past, the DDR Museum focuses on everyday life in the DDR. From sitting in a Trabant to looking at a kitchen spice rack, this museum is about the daily lives of the DDR citizens. This museum is not targeted to the East Germans who lived this daily life for up to forty years but to those who have only heard about the DDR and what life was like during those years. The DDR museum plays a bit on Ostalgie (nostalgia for the DDR), but also on the desire to share the everyday past with foreigners. The museum has about fiftyfive percent youth visitors (ages 16-29). ${ }^{43}$ Thus the hands-on experience and interactive website appeals well to its intended audience.

Most of the museum's visitors hail from former FRG and other European countries, however about twenty-three percent of visitors are from former East Germany.$^{44}$ This shows that it is not specifically a tourist museum and that it holds up historic standards enough that many Germans (from both former East and West) would visit it. With thirteen percent of the total being from former East and West Berlin, it is appealing to the native population as well as tourists. ${ }^{45}$

The DDR Museum is a privately owned and operated museum. It is made clear in the "About Us" section that they "don't spend one cent of public money and achieve no aid money." 46 The brief "About Us" description is completely about funding and indicates that that this information is important for both German and foreign audiences.

\footnotetext{
43 "Statistics," DDR Museum, accessed June 2, 2013, http://www.ddr-museum.de/en/media/charts/.

44 Ibid.

45 lbid.

46 “About Us," DDR Museum, accessed February 16, 2013, http://www.ddr-museum.de/en/museum/institution/.
} 
The museum emphasizes that the state does not control the content and that it needs to charge the stated entrance fee to keep the institution financially stable.

\section{DDR Museum Website}

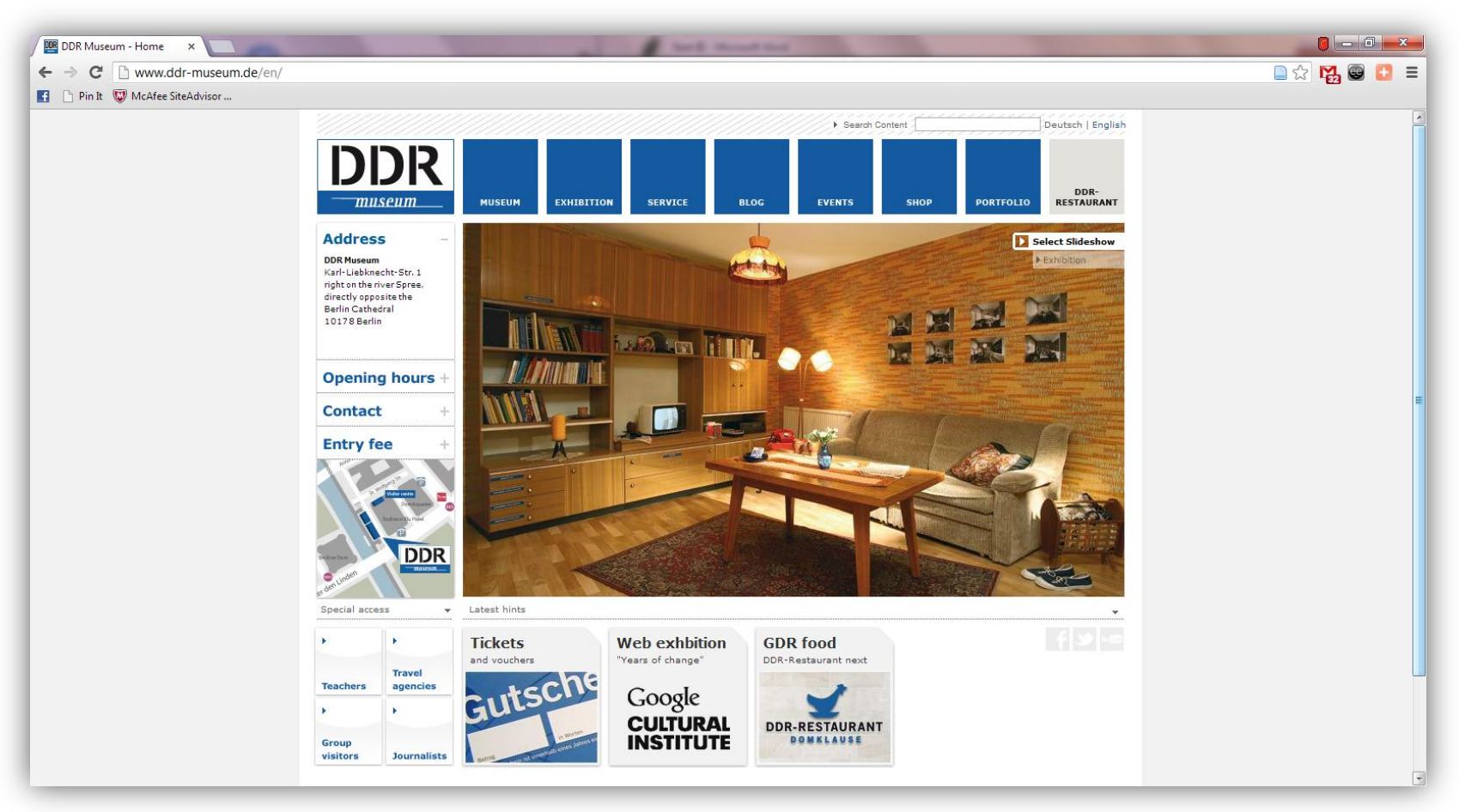

Figure 2. Screenshot of the DDR Museum webpage. [English]. Accessed February 16, 2013. http://www.ddr-museum.de/en/.

The website of the DDR Museum was launched at its opening in 2006 and revamped in $2009 .^{47}$ The website is very user-friendly and informative. It is an educational tool for both the German and English web visitor. It utilizes text, visual images, and video to show, explain, and describe the museum. The language translation from German to English is generally well-done and understandable to a

\footnotetext{
${ }^{47}$ Melanie Alperstaedt, e-mail message to author, February 12, 2013.
} 
native English speaker. The website is easy to use for young and old alike. It offers user-friendly and easy-to-locate information, but at the same time is complex, offering much to read, find, and learn. The target audience knows the basics about former East Germany but does not know the whole story; on the website its authors write "maybe you know the Spreewald pickles, nudism beaches and the Trabi - the rest of the life in this socialist state is unfamiliar to most of the people in the world." ${ }^{48}$

The site focuses more on the daily life of the citizens than the crimes of State Security or border control. The language on the site distances the museum from the old regime enough to show that it is not an Ostalgie museum; however, it does not use language that disinherits the system as part of the past. This museum is not as focused on the politics of the situation as it is in showing how people experienced life differently during this time. From soccer (Fußball) games between the two Germanies to kitchen spices, this museum is more about the human experience than the political one.

The mission of the museum is to "raise curiosity for history, combine education and entertainment, to be thought provoking, and to promote understanding between people." ${ }^{49}$ Although the theme of everyday life in the GDR is understandably for tourists and not particularly for former East Germans, the museum does at least attempt to incorporate education and historical understanding.

This museum also focuses on hands-on and interactive experiences. According to its website, the DDR Museum is "one of the most interactive museums in the world." The museum itself is not the only interactive part of its intended outreach; the website is

\footnotetext{
48 "Museum," DDR Museum, accessed February 16, 2013, http://www.ddr-museum.de/en/museum/.

49 "FAQs," accessed May 30, 2013, http://www.ddr-museum.de/en/media/faqs/.

50"Museum."
} 
very interactive as well. The DDR Museum has teamed with Google Cultural Institute to create online exhibitions. The Google Cultural Institute helps to preserve and promote culture online.$^{51}$ It strives to create "visually rich and interactive online experience for telling cultural stories in new ways" and offers online exhibits created by expert curators and engineers from around the world. ${ }^{52}$ Many non-German visitors can log on, have the text translated to their language, and see the online exhibit of "Years of Change," comprised of diary entries and photographs from May 6, 1989 -October 2, $1991 .^{53}$

In addition to this online exhibit there is also an Exhibit Database. ${ }^{54}$ Here, web visitors can search any item and get an instant list of images, names, and descriptions of all items that match the search. This is a great tool for researchers, fellow museum curators, or those simply curious about the items the museum has in the collection. The site says that the museum welcomes loan requests as well as requests for information from journalists. ${ }^{55}$ Unfortunately, this particular aspect of the website is only in German, but it recognizes this aspect with the explanatory statement: "As our research staff is German, we do our work in German. Please understand that therefore the database is in German only!" ${ }^{\prime 6}$

A blog is also available to the website visitor. The general blog can be divided into subcategories that include "Director's Blog," "Museum News," "Exhibition News," and "Topic: GDR." This allows quick access to the topics visitors would want. It seems

\footnotetext{
51 "About," Google Cultural Institute, accessed April 3, 2013, http://www.google.com/culturalinstitute/about/.

${ }^{5}$ Ibid.

53 "Years of Change: A Typical Diary from the Time of German Reunification," DDR Museum. Google Cultural Institutions, accessed March 12, 2013, http://www.google.com/culturalinstitute/?hl=enGB\#!exhibit:exhibitld=gQD0zxxl.

54 "Exhibit Database," DDR Museum, accessed February 16, 2013, http://www.ddr-museum.de/en/museum/exhibitdatabase/.

${ }^{55} \mathrm{Ibid}$.

${ }^{56}$ Ibid.
} 
to be updated frequently, showing the web audience that both the information on the blog and elsewhere on the site is current.

A web visitor can even take a video tour of the entire museum. Knowing that many of the visitors would not be German, the video is only visual with music as audio so there is no language barrier even with the video material. The international audience is definitely taken into account with this website.

\section{Conclusion}

Germany is not new to facing difficult pasts with remembrance, in fact there is a specific word_-Vergangenheitsbewältigung — that means accounting for or coping with the past. Before the issue of communism and the Stasi, Germany was already dealing with the grim memory of the Holocaust. Both East and West Germany dealt with concentration camp preservation and memorialization. Once Germany was reunited, large memorial projects such as the Memorial to the Murdered Jews of Europe in Berlin were established and showed the world that Germans were facing their own sordid past.

Dealing with the intense and emotional memory of Holocaust set a precedent of public remembrances, memorials, and education on difficult historical issues. While the Stasi Museum and the DDR Museum are independently run by private groups, they realize the seriousness of the time period they represent. Their websites are professional and the DDR Museum's is very interactive. Perhaps the only element missing on the DDR Museum site would be open sourcing where those who 
experienced life in East Germany could contribute their stories or address what they saw in the museum.

While these websites may not be perfect, they are comparable to or more informative than other history museums in Berlin. For example, the Marienfelde Refugee Center Museum is a museum in Berlin dedicated to the history of flight and emigration in divided Germany. Its website is professional, offering brief histories of East Germany and information about the museum and its programs. The site is completely translated into English for international guests. The site offers photos from the museum's collection as well as an in-depth history about an "Object of the Month." 57 It is comparable to the Stasi Museum site, although it does not feature as many interactive or multimedia options as the DDR site. Overall, though, these museum sites all present their museums to the public very well.

The DDR Museum is frequently on Top 10 lists of best museums or must-see institutions in Berlin and the Stasi Museum preserves the headquarters of the Stasi and history of the former secret police. The museums and their websites are well-presented and they serve the purpose of informing the public about their country's important history as well as showing that Germany is ready and even comfortable about facing its past.

57 "Object of the Month." Marienfelde Refugee Center Museum, accessed April 3, 2013. http://www.notaufnahmelager-berlin.de/en/object-of-the-month-564.html. 


\section{Chapter Three: Poland}

Although Poland was one of first countries to throw off the shackles of the communist regime, it was not the first country to begin to deal with the memory of it. ${ }^{58}$ With Round Table talks and rapid changes in the political system and economy, the creation of a museum or communist remembrance was set aside as a less-important issue, one to be dealt with later.

The Soviet-style of communism had never really resonated with Polish citizens. Before WWII, Poland had rebuilt an independent but multinational state. ${ }^{59}$ The "romantic uprisings" of the nineteenth century and the upheavals of 1918-1920 led to more struggle for which land belonged to whom ${ }^{60} \mathrm{~A}$ tragic gibe in the 1930 s was "What is the right answer to the question: Who is Poland's worst enemy, the Soviet Union or Germany? The Germans will take our body, and the Soviet Union will take our soul." ${ }^{61}$

After WWII the border changes and the genocide of the Jews made the nation more ethnically homogenous and the Catholic Church brought the Polish nation together further under a single religion. ${ }^{62}$ The communist regime lacked legitimacy from the start because it was imposed by "an unpopular outside force that had long been Poland's enemy." ${ }^{63}$ Communism was never really a part of the Polish identity or national feeling and this may be a reason for the lack of a museum and different approaches of remembrance and education.

\footnotetext{
${ }^{58}$ Robert Kostro, "The Light of History: Through the Lens of a Polish Museum." in Entering the Minefields: the Creation of New History Museums in Europe. Conference Proceedings from EuNaMus, 74.

59 Jane Leftwich Curry and Luba Fajfer, eds. Poland's Permanent Revolution: People vs. Elites, 1956 to the Present, (Washington, DC: The American University Press, 1996), 6.

${ }^{60}$ Andrzej Paczkowski, The Spring Will Be Ours: Poland and the Poles from Occupation to Freedom, trans. Jane Cave (University Park: The Pennsylvania State University Press, 1998), 36.

61 lbid, 36.

62 Curry and Fajfer, Poland's Permanent Revolution, 6.

63 Ibid, 6.
} 
Poland does not yet have a museum of communism. Of course, the idea was proposed and even made it through the Warsaw city government. The former mayor of Warsaw, Lech Kaczynski, initially decided on the creation of a Museum of communism in $2003{ }^{64}$ Other museums in Poland appeared around this time, such the Warsaw Rising Museum and the European Solidarity Center in Gdansk. A team was assigned to the project of a museum of communism and a budget was determined, but that faded as the government changed. The number of members on the museum team was cut as well as the budget. ${ }^{65} \mathrm{~A}$ small venue for the museum in the Palace of Culture and Science was proposed, but for now there are only temporary exhibitions. ${ }^{66} \mathrm{~A}$ museum of communism is not something that is demanded by the citizens of Poland or Warsaw and so it is not a high priority project for officials. Perhaps one day the plans will be revisited.

\section{Institute of National Remembrance, Warsaw}

Although not a museum, the Institute of National Remembrance was created in 1998 and has produced and housed temporary, traveling exhibits that serve to educate the population about the nation's history. Dariusz Stola, a historian, writes that the idea to establish a separate public institution to deal with security files was modeled after Germany's Gauck/ Birthler Institute ${ }^{67}$ The Institute of National Remembrance has a

\footnotetext{
64 Dariusz Bartoszewicz, "Muzeum Komunizmu do Lamusa? Władze rezygnują." Gazeta Wyborcza, (August 10, 2011), accessed March 23, 2013, http://wyborcza.pl/1,76842,10098597,Muzeum_Komunizmu_do_lamusa_Wladze_rezygnuja.html. 65 lbid.

66 Ibid.

67 Dariusz Stola, "Poland's Institute of National Remembrance: A Ministry of Memory?" in The Convolutions of Historical Politics, ed. A. Miller and M. Lipman (Budapest: Central European University Press, 2012), 48.
} 
very broad mission, but I will focus on the historic exhibitions and education portion of the IPN.

Unlike many of its neighboring countries, Poland was late to deal with such issues as secret police files and lustration. It was not until 1998 that the first attempts at creating an institution to deal with the communist past were initiated. ${ }^{68}$ Pawel Machcewicz, a historian, writes that there were several reasons for this, including the regime's "less repressive nature" as well as the different (negotiated) way the dismantling of communism was handled. ${ }^{69}$ This allowed for more of a dialogue between state and society and a lesser need to punish former communists.

The Institute for National Remembrance is now one of Poland's largest public institutions, employing some 2,200 persons. ${ }^{70}$ Nearly twenty-eight percent of those employees are office workers, ironically causing the IPN to be "bureaucratic, centralist, heavy, inclined to extensive growth and quantity rather than quality of production, and decreasingly effective," according to Stola.

The IPN's responsibilities include the maintenance of archival records, research, education, prosecution of perpetrators of crimes committed at the time, and verification of vetting declarations. ${ }^{71}$ The Institute of National Remembrance has prepared more than a dozen traveling exhibitions aimed at both Polish and international audiences.

\footnotetext{
${ }^{68}$ Paweł Machcewicz, "Poland's Way of Coming to Terms with the Legacy of Communism," Eurhistxx, accessed April 20, 2012, http://www.eurhistxx.de/spip.php\%3Farticle40\&lang=en.html.

69 Ibid.

${ }_{71}^{70}$ Stola, "Poland's Institute of National Remembrance," 53.

71 "The Institute of National Remembrance Guide," The Institute of National Remembrance, (Warsaw 2009), accessed February 13, 2013, http://ipn.gov.pl/_data/assets/pdf_file/0019/94150/Guide-2009.pdf.
} 
The IPN has featured the following topics in its traveling displays and curriculum:

- "The Phenomenon of Solidarity. Pictures from the History of Poland, 1980-1981"

- "Cold War. Short History of Divided World"

- "Polish Peoples' Republic: So Far Away, So Close..."

- "The Destruction of the Polish Elite, Operation AB - Katyń"

- "Battle of Britain"

- "In search of reconciliation. With open hands. Cardinal Adam Kozlowiecki, SJ"

- "Executed cities. Poznań - Budapest 1956"

- "In Big Brother's Arms - The Soviets in Poland 1944 - 1993"

- "Blood of the workers will not have been spilled in vain"

- "Archbishop Ignacy Tokarczuk - church, government, social resistance"

- "Righteous Among the Nations. Polish help for Jewish population in the south-eastern part of Poland in 1939-1945"

- "Rotamaster Witold Pilecki - volunteer to Auschwitz"

- "March 1968 "

- "Our pastor and us. Father Jerzy Popiełuszko in photographs and memories of Jerzy Szóstka"

- "...and files to be destroyed. The archives of the communist repressive apparatus in Poland and other European countries"

- "Multiplying good"

- "The Katyń Massacre"

- "The Expelled"72

The topics which the Institute of the National Remembrance has selected reflect the parts of history that are important to Poland and events that were taboo under the communist regime, such as "The Katyń Massacre." These displays and educational

72 "Exhibitions," The Institute of National Remembrance, http://ipn.gov.pl/en/exhibitions. 
materials are a way of reclaiming earlier history that was not allowed to be discussed and taught. The institute also makes an effort to branch out from the solely Polish history and memory to include other nations' histories, such as the Battle of Britain, as well as broader topics like "Cold War, A Short History of Divided World," in which Poles directly participated. It includes one on Polish help for the Jewish population during the war as well as one on Polish workers. The IPN presents a wide-range of topics in their educational displays and histories; the problem is that this state-sponsored institute tends to depict the role of Polish society in $20^{\text {th }}$-century history in a good and honorable light, characterizing Poles as the freedom fighters, civilian resisters, and innocent victims that were crushed by the cruel and distant Soviet-backed communist regime. ${ }^{73}$ Yes, there were many honorable Polish citizens who helped the Jewish population during the war, but what about those who collaborated with the Germans, those who stood by idly while people were taken away, those who supported the communist government and adapted to the regime? History is fraught with misdeeds on all sides and the full story must be portrayed. Stola writes that the IPN scholars "underestimate the size and role of the gray zone in-between the poles, the [attitudes] that do not fit with the polarized image of the "the regime vs. the people."'74 Stola continues, that this is in part because of the IPN's mission statement, which is to inform about the communist oppression, to educate about resistance by Poles and to commemorate the martyrs and heroes of the nation. ${ }^{75}$ In the early years, this focus was understandable as they were making up for years of repressed memory; however, as the years go on there is limited

\footnotetext{
${ }^{73}$ Stola, "Poland's Institute of National Memory," 56.

74 Ibid, 57.

75 lbid, 57.
} 
mention of other topics pertaining to the history of the time period and full stories of collaboration, apathy, and accounts of daily life experience. ${ }^{76}$

Stola writes that "in general, there are no good reasons to make a history research institute part of the government." ${ }^{77}$ Questions over full freedom of opinion and writing outside of the mission statement are just a few concerns of government-funded history, not to mention the role of a civil servant framing historical narratives as opposed to independent researchers and academic historians. ${ }^{78}$ Initially, very limited physical space for researchers as well as long wait times did not cater to those academics wanting to use files for their own research ${ }^{79}$, although this has changed in recent years. Moreover, the IPN scholars often tend to publish trivial or useless volumes instead of taking into consideration what would be most useful for academics and other researchers. ${ }^{80}$ Because it is such a large institution, its practices tend to restrict (downcut) the flow of information both internally and for outsiders.

\footnotetext{
${ }^{76} \mathrm{Ibid}, 57$.

$77 \mathrm{lbid}, 53$.

${ }^{78} \mathrm{lbid}, 53$

${ }^{79}$ lbid, 54.

${ }^{80} \mathrm{lbid}, 54$.
} 
IPN Website

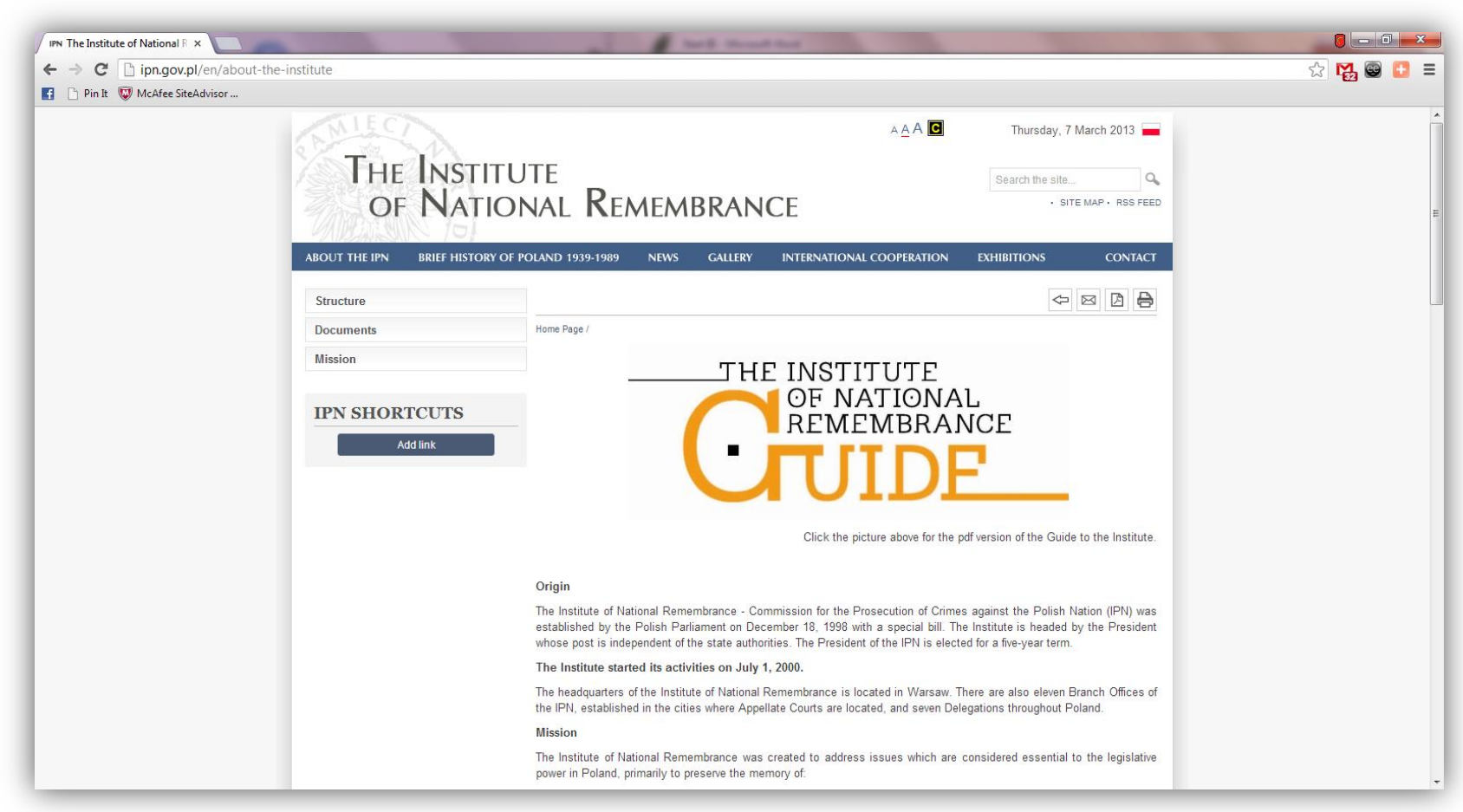

Figure 3. Screenshot of the Institute for National Remembrance website. [English]. Accessed February 13, 2013. http://ipn.gov.pl/en/about-the-institute.

The Institute for National Remembrance website is very visitor-friendly. The web visitor may view it in Polish or English. It is targeted to a visitor that has little to no knowledge of the communist era in Poland. In the "About the IPN" section, a web visitor can print The Institute of National Remembrance Guide which is a very basic educational guide about what the IPN is and what it does as well as brief recent history and geography of Poland. This website is geared to people who want to learn the basics about the institution and why it exists.

The website has a wide target audience from middle-grade students to senior citizens. It has a user-friendly display and makes it relatively easy to find topics in which 
visitors would be interested. However, the lack of many interactive components and only a .pdf file to print out make it geared to a slightly older audience.

The IPN and its literature tend to portray the Polish nation in a favorable light. Communism is characterized as alien to the nation of Poland, externalizing the "totalitarian regime....which ruled over Poland." ${ }^{81}$ This not only appears in the publications coming out of the IPN but also on the website and in the IPN public guide. Writing communism off as something that was merely thrust upon Poland does not delve into the deeper history of the situation or lived experiences under communism.

For visitors who do not download the .pdf guide, there is a brief history of Poland under fascism, war occupation, and communism (1939-1989). It explains how those fifty years are significant and are the years that the Institute of National Remembrance focuses on in its work. The website also includes a layout of the IPN with flow charts of the council and departments, the full texts of the legislative acts that pertain to the IPN, as well as the mission statements and various other official documents. Someone with no idea of what had happened in Poland during the last century could get a basic understanding from this page.

This website provides a small photo gallery, some current news pertaining to the IPN, an explanation of International Cooperation, and a list of all the exhibitions the IPN has displayed. The Institute of National Remembrance has prepared more than a dozen physical exhibits aimed at the international audience.

These exhibits are not just shown at the institute in Warsaw, but travel around Poland and even abroad. The exhibits are usually constructed out of light and simple

\footnotetext{
81 "The Institute of National Remembrance Guide."
} 
materials so they can easily be transported and installed. ${ }^{82}$ This makes it easy to display in "small towns, schools, community centres, and regional museums." ${ }^{83}$ The IPN has been diligent about bringing selective Polish history—especially modern Polish history— to the public consciousness. It features everything from national history competitions to public lectures and lessons. I attended a three-part course taught in English at the IPN, the first topic on the years 1945-1956, the second about 1956-1970, and the third about 1970-1989. These courses were informative; the bias of a government institution painting Poland in a favorable way was notable. These public lectures and classes offered in different languages do, however, help with historical outreach and awareness.

This website branches off to many IPN-made thematic websites that offer much more historical information and interactivity. Some of these sites are completely dedicated to a single person, important to the Warsaw Uprising or the Home Army, for example. One site is dedicated to the year 1989 in several Central/Eastern European countries. Another is dedicated to Martial Law in Poland and its victims. Some are quite interactive where the web user can click on objects and an informative window pops up to give the history. Others include many photographs and video content. They all add significantly more historical background and information to the main IPN site. In addition to these six thematic websites, the main site offers an extensive list of additional websites for visitors to view including partner institutions, museums, archives, and general sites about related topics.

The English translation on the site is excellent, making it accessible to the international audience. It offers good, clear information about the Institute for National

\footnotetext{
82 Ibid.

${ }^{83}$ Ibid.
} 
Remembrance and a brief Polish history; good English translations characterize as well the additional websites it provides on the main page.

\section{Conclusion}

The Institute of National Remembrance exists to show the priority of official discussions in Poland about the recent past. While a museum of communism never was established, the government created a huge institute dedicated to "inform about the communist institutions of oppression, educate about the resistance against the regime and commemorate its martyrs and heroes." ${ }^{84}$ The IPN is not the only institution in Poland that was established to preserve the memory of the communist era in Poland. In Gdansk, the European Solidarity Centre (ECS) was established on November 8, 2007 by representatives of government and NGOs, including the Minister of Culture, the Marshall of the Pomeranian Voievodship, the President of Gdańsk, the President of the European Solidarity Centre Foundation, and the Chairman of the NSZZ Solidarność Trade Union. ${ }^{85}$ The European Solidarity Centre was established "to preserve the heritage and retain a fond memory of Solidarność in order to hand it down to future generations, while stressing its relevance and universal value." ${ }^{86}$ As discussed before, the IPN generally shows Poland and Polish citizens in a favorable light, depicting them as victims of a foreign and cruel communist regime. The ECS states directly in its mission statement that it is the wish to retain a fond memory of Solidarność, thus preserving a positive image and leaving any contrary memory out of the way.

\footnotetext{
${ }^{84}$ Stola, "Poland's Institute of National Remembrance.", 57.

85 "About Us," European Solidarity Centre, accessed March 27, 2013, http://www.ecs.gda.pl/About_us.

86 Ibid.
} 
The KARTA Center in Poland is another organization that is dedicated to promoting democracy and providing knowledge about the past. KARTA is an independent non-governmental organization involved in the documentation and dissemination of the recent history of Poland and Central and Eastern Europe. ${ }^{87}$ Its website provides programming, informative literature, hundreds of historic photographs depicting mostly people (some depict war life and others leisure and entertainment), and partner links. This organization is focused on providing information and history to Polish citizens and speakers, as is evident in the lack of English translation on the site.

Certainly, this feeling and need to make up for past oppression is justified; however, it cannot get in the way of representing the whole story. As historical institutions, they cannot hide events of collaboration or silence in order to portray a nation in a good light. Only in limited individual cases has there been a clear divide between total victim and total perpetrator. A nation certainly wants to promote moments of pride and honor from the past, but history must be told in its full version.

87 “Home," Ośrodek KARTA, accessed March 30, 2013, http://www.karta.org.pl/index.php. 


\section{Chapter Four: The Czech Republic}

Former Czechoslovakia, like most of Europe, has had a rapidly-changing recent history. Now the separate states of the Czech Republic and Slovakia, the former Czechoslovakian state was victim to several occupations. The state was originally formed in 1918 from several provinces of the former Austria-Hungarian Empire after the collapse of the Hapsburg Empire. ${ }^{88}$ It was a single nation created out of two "distinct yet kindred" people. ${ }^{89}$ For more than seventy years Czechs and Slovaks lived together in the nation state of Czechoslovakia.

The first republic was a relatively stable and democratic political entity until it was occupied by Nazi Germany in $1938-1945 .^{90}$ The country came under Soviet domination in 1948 and remained so until independence in 1989.

One of the important events during this period was the Prague Spring and Soviet invasion of 1968 . The 'Prague Spring' was a reform movement followed by a brief struggle for power between Czechoslovakia and the Soviet Union. ${ }^{91}$ Alexander Dubcek was the First Secretary of the Communist Party of Czechoslovakia and was a popular leader, known for the phrase "socialism with a human face." ${ }^{.92}$ He took cautious steps toward relaxation of censorship, expressed wishes to respect the rights of working people, and made a move toward decentralization of administrative authority. ${ }^{93}$ The Warsaw Pact armed forces arrived in Czechoslovakia to prepare for military maneuvers

\footnotetext{
${ }^{88}$ Maria Dowling, Czechoslovakia (London: Oxford University Press, 2002), ix.

${ }^{89} \mathrm{lbid}$, ix.

${ }^{90} \mathrm{lbid}$, ix.

${ }^{91}$ Ibid, 105.

92 Ibid, 107.

${ }^{93}$ Ibid, 108-110.
} 
including the arrival of tanks. ${ }^{94}$ There was non-violent protest but no military resistance and Czechoslovakia remained controlled until 1991.

The Prague Spring was followed by a long period of 'normalization'. In 1992, Czechoslovakia separated into two separate states of Czech Republic and Slovakia during the 'velvet,' and quite amicable, divorce. ${ }^{95}$ The reasons for the 'velvet divorce' were "ethnic, economic, and political."

\section{Museum of Communism, Prague}

Every museum has a different story of origin and the Czech Republic's Museum of Communism is no different. A headline in 2001 declares "Bagel King opens Czech Republic's First Museum of Communism." ${ }^{97}$ American businessman (of Czech origin) ${ }^{98}$ Glenn Spicker founded the Czech Republic's first museum of communism. ${ }^{99}$ Situated "above a McDonalds and next to a Casino," it is ironic that a museum displaying the history of a fiercely anti-capitalist regime is situated "in the heart of consumer capitalism." ${ }^{100}$ As a true capitalist, Mr. Spicker saw another business opportunity (in addition to his bagel company) and decided to open a Museum of Communism. He, along with Czech documentary filmmaker Jan Kaplan, worked on the project, collecting many of the artifacts themselves from antique stores and bookshops. ${ }^{101}$ Spicker said

\footnotetext{
94 Ibid, 112.

95 lbid, ix.

${ }^{96} \mathrm{Ibid}, 160$.

97 lamn Willoughby, "Bagel King Opens Czech Republic's First Museum of Communism," Czech Radio 7, Radio Prague, (2001), accessed March 7, 2013, http://www.radio.cz/en/article/12239.

${ }^{98}$ Drakulić, A Guided Tour, 6.

99 Willoughby, "Bagel King."

${ }^{100}$ Drakulić, A Guided Tour, 6.

101 Willoughby, "Bagel King."
} 
that he expected criticism for being a foreigner, but his museum has generally been accepted. ${ }^{102}$

The theme of the museum is "Communism--the Dream, the Reality, and the Nightmare." ${ }^{103}$ This theme tries to incorporate all aspects of the experience. "The dream" is expressed as the utopian ideal of communism. ${ }^{104}$ The examples of "the reality" include the long lines for scarce groceries and public telephones that never worked. ${ }^{105}$ "The nightmare" is the portrayal of the secret police using surveillance, censorship, and imprisonment to silence dissent. ${ }^{106}$ Anyone with a public history background would certainly question a museum that was designed and created primarily by a businessman and a documentary filmmaker. Digging through rummage sales and antique shops is not the way to create a collection for a museum. With no trained curator or historian, this museum is more a recreated set of images than a historical lesson and interpretation of the past. Each item selected and displayed is very important and should be subjected to careful research by historians and curators, not based on what could be found in old shops. However, quoting again Drakulić, "the importance of it is that it exists." ${ }^{107}$

The museum has made the image of the Matryoshka nesting doll with teeth rather famous. It is an image that catches the tourist's eye. This image, a humorous take on a popular Russian toy, also depicts the feeling towards the former Soviet Union

\footnotetext{
102 Ibid.

103 "About the Museum," Museum of Communism, accessed February 2, 2013, http://www.muzeumkomunismu.cz/.

${ }^{104}$ Katka Krosnar, "A Tribute to Barren Shops," Newsweek, February 10, 2002, accessed March 20, 2013, http://www.muzeumkomunismu.cz/articles/newsweek.htm.

105 lbid.

106 Ibid.

${ }^{107}$ Drakulić, A Guided Tour, 25.
} 
and shows that the USSR had the "sharp teeth" while Czechoslovakia is obviously the victim ready to be attacked by this vampire-like figure.

The mission of the museum is clearly touristic. The museum's creation by an American businessman with little help from scholars or curators makes it clear that this museum is responding to an opportunity for profit more than a desire to share and interpret the past for the public. The museum is located in the tourist section of town and is obviously marketed to a non-Czech population. Even the sign shown below only features English information, clearly showing its intended audience is a foreign one.

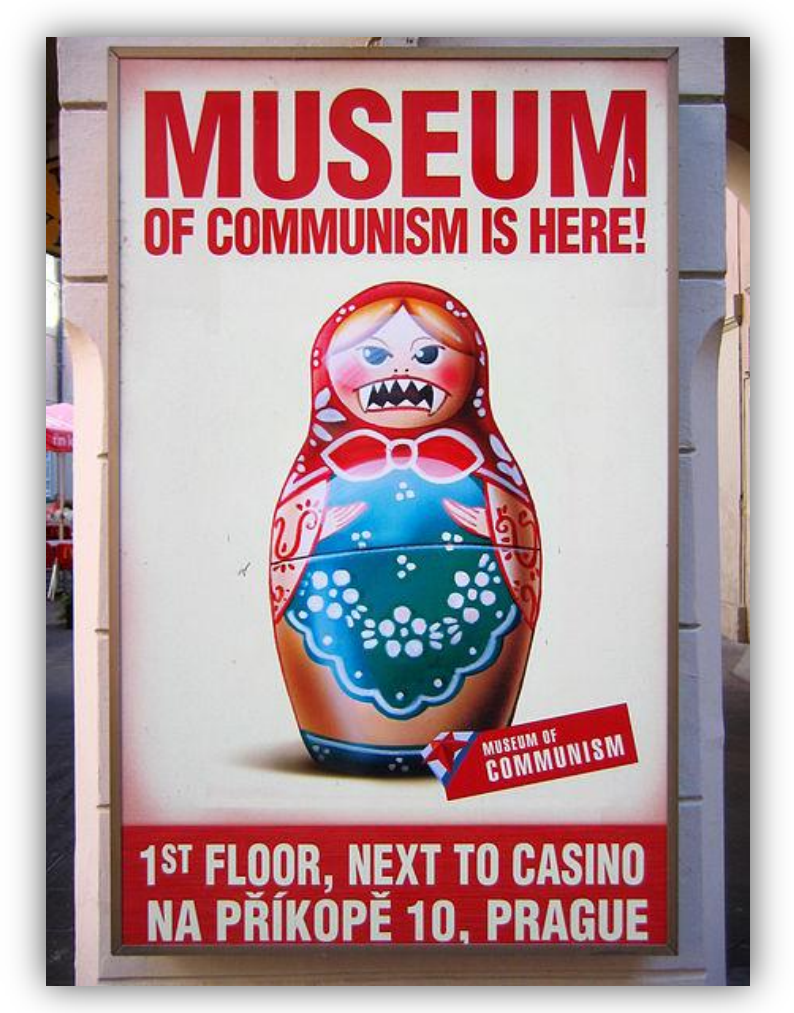

Figure 5. Museum of Communism poster displays Matryoshka doll with sharp teeth.

Image credit: Wikimedia Commons 


\section{Museum of Communism Website}

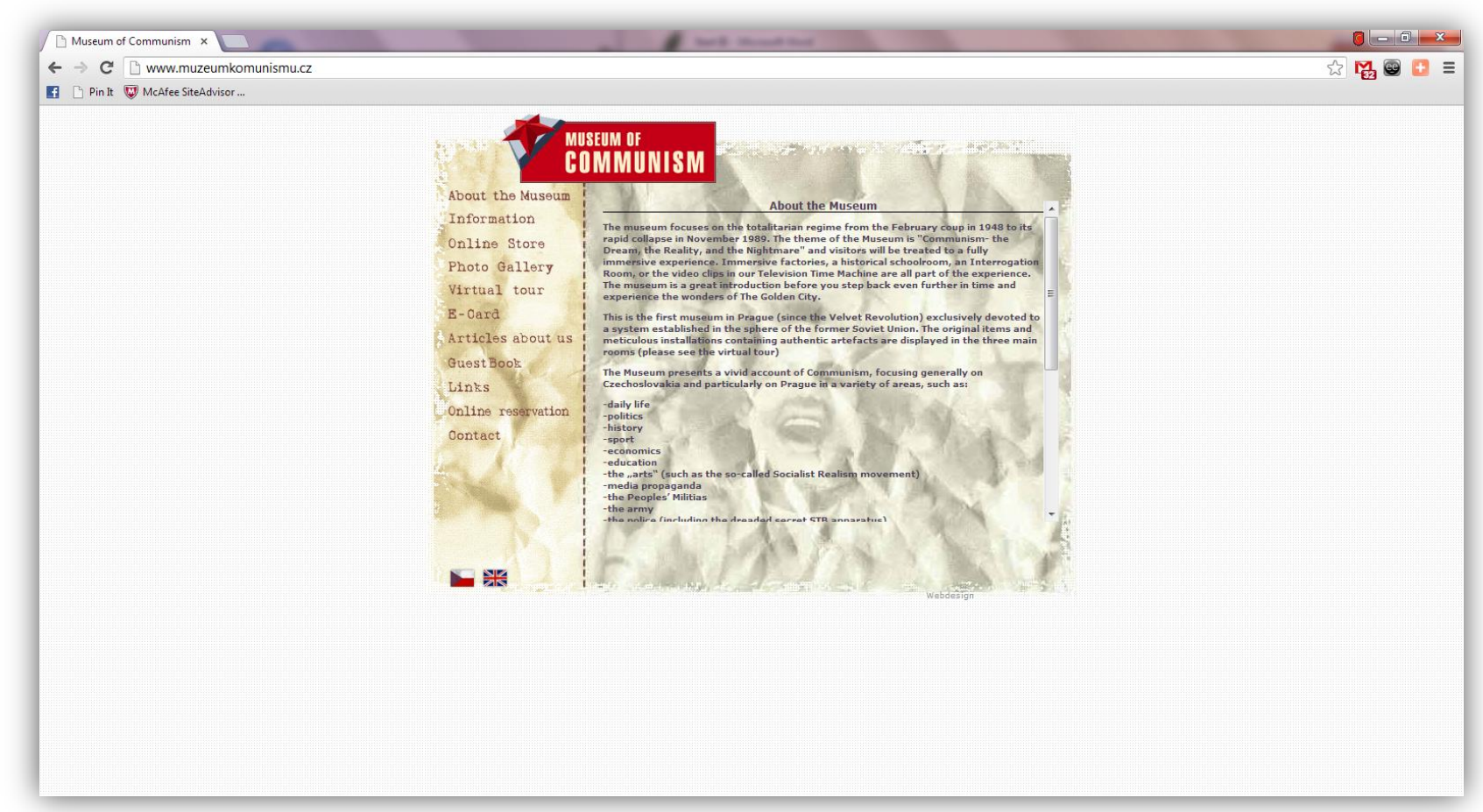

Figure 6. Screenshot of Museum of Communism webpage. [English]. Accessed February 2, 2013. http://www.muzeumkomunismu.cz/.

The Museum of Communism website does not appear to be a professional site. The first thing an English or Czech visitor would notice is that the website is not formatted to be full-screen so the font is not a comfortable reading size to obtain information. Education material is apparently available, but not accessible on the website; one must e-mail a contact person for a copy of the "educational worksheet."108 When a visitor clicks on the online store tab, a white page pops up with the words "Eshop is out of order till June 2011, we are sorry." ${ }^{109}$ The photo gallery offers three lowresolution photos and the virtual tour runs on an out-of-date Java plug-in that makes it

\footnotetext{
108 "Educational Activities," Museum of Communism, accessed February 2, 2013, http://www.muzeumkomunismu.cz/eng_educational.html.

109 "Online Store," Museum of Communism, accessed February 2, 2013, http://www.muzeumkomunismu.cz/eng_photos.html.
} 
difficult to access at all. The "Articles About Us" section does offer several articles in Czech and English, but they are only about the museum and do not offer information for further research on Communism or the Czech Republic (and even among the links, some of them are dead). ${ }^{110}$ The Online Guestbook shows an error code and the last reviews written were in mid-2012. ${ }^{111}$ Showing its privately-owned roots, the website advertises for other Prague attractions and offers tourism links to web visitors. The website offers an on-line reservation form for tours and some basic contact information for the museum.

The English is excellent (hopefully so with an American owner) and it is easy to locate the English and Czech language links at the bottom of the screen. Whether it was the initial goal or just the outcome, this website is geared more to an older audience. It is obvious that the website was not a priority and there are no apparent information technology experts on the staff of the museum. It is mainly for people who are just looking for basic museum information and nothing more. It has only out-dated interactive components.

The website does not provide much general history about communism in general. In fact, it says very little about the history the museum covers, with only a few dates about when communism existed in Czechoslovakia. However, as Drakulić notes, the museum displays the country's opposition to communism while leaving out the percentage of pro-communist voters in postwar elections. It is obvious that the mission

\footnotetext{
110 "Articles About Us," Museum of Communism, accessed February 2, 2013, http://www.muzeumkomunismu.cz/eng_articles.html.

${ }_{111}$ "Guestbook," Museum of Communism, accessed February 3, 2013, http://www.muzeumkomunismu.cz/eng_guestbook.html.
} 
of this museum is to attract tourists and not to truly educate them about the realities of the communist experience in the Czech lands.

The website, besides being somewhat aesthetically displeasing, uses few resources the web now has to offer. As a privately-owned museum that depends on profit, it is quite surprising that the website appears this way and is not very informative. It is in sharp contrast to the similarly privately-owned tourist museum of the DDR.

The Museum of Communism is not the only voice of communist memory. In addition, there is the Ośrodek KARTA center, which like its Polish counterpart, is an independent, non-governmental organization dedicated to documenting and popularizing contemporary history of Central and Eastern Europe. ${ }^{112}$ In contrast to the Polish KARTA, its website provides much more information on the history of communism in English and other languages in an effort to reach a wider audience. Its main focus is on "experiences and attitudes of individuals who were living, suffering, dying - but also resisting - totalitarian regimes." 113

\section{Conclusion}

The Museum of Communism boasts that it is "the first museum in Prague (since the Velvet Revolution) exclusively devoted to a system established in the sphere of the former Soviet Union." 114 The first museum dedicated to communism in Czechoslovakia was established by an American businessman and a documentary film maker, showing

\footnotetext{
112 “Home," Ośrodek Karta, accessed April 3, 2013, http://www.pametnaroda.cz/institution/detail/id/25.

113 lbid.

114 "About the Museum," Museum of Communism, accessed February 2, 2013, http://www.muzeumkomunismu.cz/.
} 
that a desire for remembrance, at least in the form of a museum, was not demanded by the public or implemented by the government.

Owner Glenn Spicker told reporters that he knew that tourists would be the main visitors because "Czechs are not that excited to talk about the past." ${ }^{115}$ However, Marian Krotochvil of the Institute of Contemporary History in Prague said this was not the issue, that "the Czechs do not mind discussing things that happened during those 41 years of Communist rule" especially when talking about resistance. ${ }^{116}$ Krotochvil continues, saying that the Museum "is a damned pseudo-capitalist venture, and no Czech would ever visit it." ${ }^{117}$ Even tourists have noted that it has a Western bias. ${ }^{118}$ The Museum of Communism does not add much to historical scholarship or even public history presence in the Czech Republic. The museum was contrived and mainly designed by non-academics, people with little to no background in historical interpretation, research, public history, or museum studies. Perhaps it is useful in introducing life under communism to tourists with no previous knowledge of the country's communist history; however, it does not seem to have helped Czechs to come to terms with the past. To many citizens, it is just another tourist destination.

The Museum of Communism's website could be compared to other privatelyowned museums, such as the Jewish Museum in Prague. Also owned by a non-state entity, this museum's website is informative about the history of the museum and the collections it offers. It also features an educational online display featuring monthly

\footnotetext{
115 Jelena Kopanja, "Forty Years After Prague Spring, All That's Left of Communism is a Babushka with an Overbite," NYU Livewire, accessed March 30, 2013, http://journalism.nyu.edu/publishing/archives/livewire/archived/forty_years_aft/.

${ }_{116}$ Ibid.

117 lbid.

118 lbid.
} 
topics. ${ }^{119}$ Although not a prime example of a museum site, it shows that small, private museums can make basic efforts in making their online sites more educational for the public.

Simply because the Museum of Communism is a private museum does not make it a substandard museum; for example, the DDR Museum has done a great job of being a professional museum with online resources and professional interpretation. The Museum of Communism and its owner have made little effort to make this museum into a reputable institution, one designed and overseen by a professional staff of historians, researchers and curators. Although Spicker did involve a Czech documentary filmmaker, only a small list of scholars were asked to participate and it did not involve any type of citizen committee for commentary or input.

119 “Home Page," Jewish Museum of Prague, accessed April 3, 2013, http://www.jewishmuseum.cz/aindex.php. 


\section{Chapter Five: Hungary}

Like Poland and Czechoslovakia, Hungary was incorporated into the communist bloc after the Second World War. In 1937 the Hungarian National Socialist Party (known as 'Arrow Cross' Party, as its symbol) was formed and created a radical right that passed anti-Jewish laws and supported Nazi Germany. ${ }^{120}$ When the German occupation was over, Hungary fell under Stalin's 'jurisdiction. ${ }^{121}$ Hungary gradually adopted a nationalized economy and collectivized farming. Soviets used 'salami tactics' to divide and conquer their opponents in the 1940s and the transition to a single party system ended what was a relatively free and prosperous era in Hungary. ${ }^{122}$

The 1956 uprising showed the people's displeasure with Hungary's communist regime. A large group of protesters -estimated at 300,000-took to the streets against the communist regime, cutting the Communist symbol out of the flag and toppling the statue of Stalin. ${ }^{123}$ The Soviet Army was called in and for five days fighting ensued. The uprising was brutally crushed by Soviet forces accounting for 2,500-3,000 Hungarian deaths. ${ }^{124}$ So, "'the first anti-totalitarian revolution' ended in a blood bath." 125 Hungary continued on its course as part of the Soviet bloc with some consolidation and reform until 1989, when a peaceful transition to a multi-party system came about after being discussed between government representatives and the opposition. ${ }^{126}$

\footnotetext{
${ }^{120}$ László Kontler, A History of Hungary: Millennium in Central Europe (New York: Palgrave Macmillian, 2002), 369377.

${ }^{121}$ Miklós Molnár, A Concise History of Hungary, trans. Anna Magyar (Cambridge: Cambridge University Press, 2001), 295.

122 Ibid, 301.

123 Ibid, 312.

124 Kontler, A History of Hungary, 429.

${ }_{125}^{125}$ Molnár, A Concise History of Hungary, 321.

126 Ibid, 337.
} 


\section{The House of Terror Museum, Budapest}

The House of Terror Museum is located in Budapest, Hungary. It was opened on February 24, 2002 on 60 Andrássy Avenue, the former headquarters of the communist secret police. This museum, like the Stasi Museum, is located in a former secret police building. While the interior design and outer façade were redone, the basement-the most shocking part of the museum - was left in its original design to show the authentic cells where prisoners were kept. This allows the audience to literally follow in the footsteps of officers and prisoners who walked these halls and prison cells. Being in the same location where many of these historic events occurred can make for a more vivid experience for visitors. The façade features a dramatic roof blade that casts the word "TERROR" on the sides of the building, "provid[ing] a frame for the museum, causing it to stand out by its sharp contrast to the other buildings on Andrássy Street, and befitting its historic significance, focuses attention on the house itself." ${ }^{127}$ Being able to redesign what was once a place of oppression and terror into a memorial helps to replace a negative image and piece of the city into something that can start a healing discourse.

This museum was established as a memorial for the victims of the "terror regimes" (the German National Socialist party, the fascist Arrow Cross party, and the Hungarian Communist Party) and to present a clear picture of what life was like during those times. ${ }^{128}$ The museum was established by The Public Foundation for the Research of Central and East European History and Society. ${ }^{129}$ The mission of the museum is to "erect a fitting memorial to the victims, and at the same time to present a

\footnotetext{
127 "About the House of Terror," House of Terror, accessed February 17, 2013, http://www.terrorhaza.hu/en/museum/about_us.html.

${ }_{128}^{128}$ Ibid.

129 lbid.
} 
picture of what life was like for Hungarians in those times." ${ }^{130}$ Memorialization of the past oppression of the Hungarian population in the twentieth century is the main focus of this museum.

The museum centers purely on victimization. It focuses on the struggle against both regimes and shows that "ultimately, the fight against the two cruelest systems of the 20th century ended with the victory of the forces of freedom and independence." 131 Its main focus is on the victims of communism rather than the less emphasized Nazi regime and its Arrow Cross collaborators. It clearly states that this museum is "a monument to the memory of those held captive, tortured and killed in this building." ${ }^{132}$ It portrays communism as something cast upon Hungarian society. This specific focus gives the museum a particular feeling of heaviness.

Architecture and design are an important part of museums, especially museums that seek the shock-and-awe feeling. James Ingo Freed, designer of the United States Holocaust Museum, said that museums must "be expressive of the event." ${ }^{133}$ Similar to the Holocaust Museum, this smaller museum uses the organization of space and materials to create the feel of "inexorable, forced movement: disruption, alienation, constriction, observation, [and] selection.." ${ }^{134}$ The House of Terror strives to create an intense feeling for the visitor with space, lighting, and a personally-composed score for the exhibits' background music.

\footnotetext{
${ }^{130}$ Ibid.

${ }^{131}$ Ibid.

132 Ibid.

${ }^{133}$ Edward T Linenthal, Preserving Memory: The Struggle to Create America's Holocaust Museum (New York: Viking, 1995), 88.

${ }^{134} \mathrm{lbid}, 88$.
} 
The museum's target groups are Hungarians and tourists alike, as it offers explanations and labels in both Hungarian and English. It is clearly marked as a tourist destination, a "must-see" of Budapest. The museum has received much praise over the years, as can be seen in the travel article in The New York Times entitled 'The Wonderful Museum of Terror in Budapest'." This article describes the museum as a "brilliant amalgam of history museum, performance art, and touching architectural memorial to all the people...who died or suffered under Hungary's sequential reigns of terror." ${ }^{135}$ There are also other voices: another article in the same publication states that the critics of the museum say that the museum and its curators were "motivated by contemporary politics." ${ }^{136}$

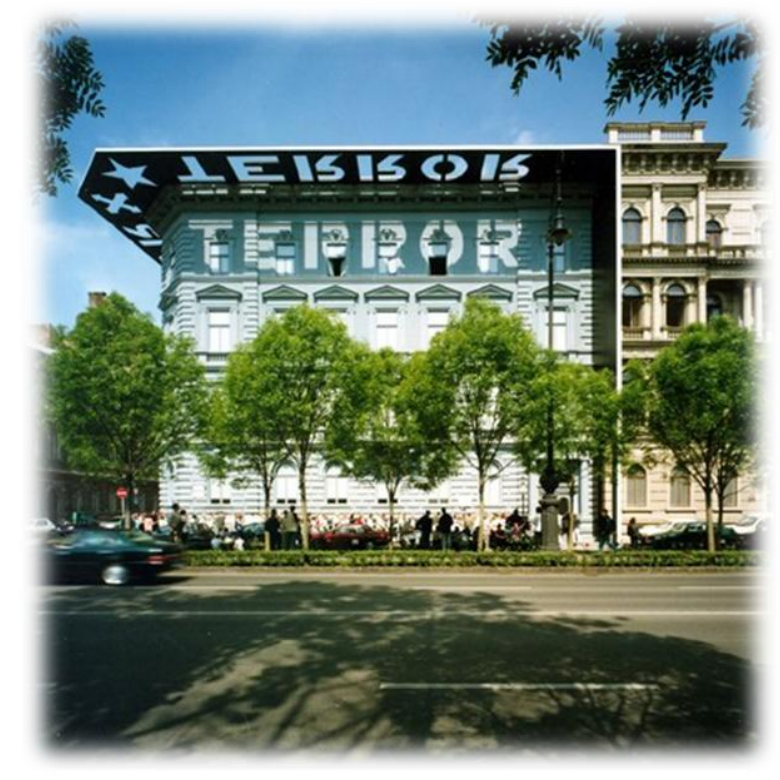

Figure 7. "House of Terror Museum, (Andrássy Street, Budapest)." Figure depicts the distinctive façade of the building with the well-known awning and shadow casting "TERROR" on each side of the building as well as a communist star and an Arrow Cross at the corner.

Image Credit: House of Terror Museum

135 "A Wonderful Museum of Terror in Budapest," The New York Times, August 20, 2008, accessed March 10, 2013, http://intransit.blogs.nytimes.com/2008/08/20/a-wonderful-museum-of-terror-in-budapest/.

${ }_{136}$ Thomas Fuller, "Stark History/ Some See a Student: Memory Becomes a Battleground in Budapest's House of Terror," The New York Times, August 2, 2002, accessed April 4, 2013,

http://www.nytimes.com/2002/08/02/news/02iht-budapest_ed3_.html. 


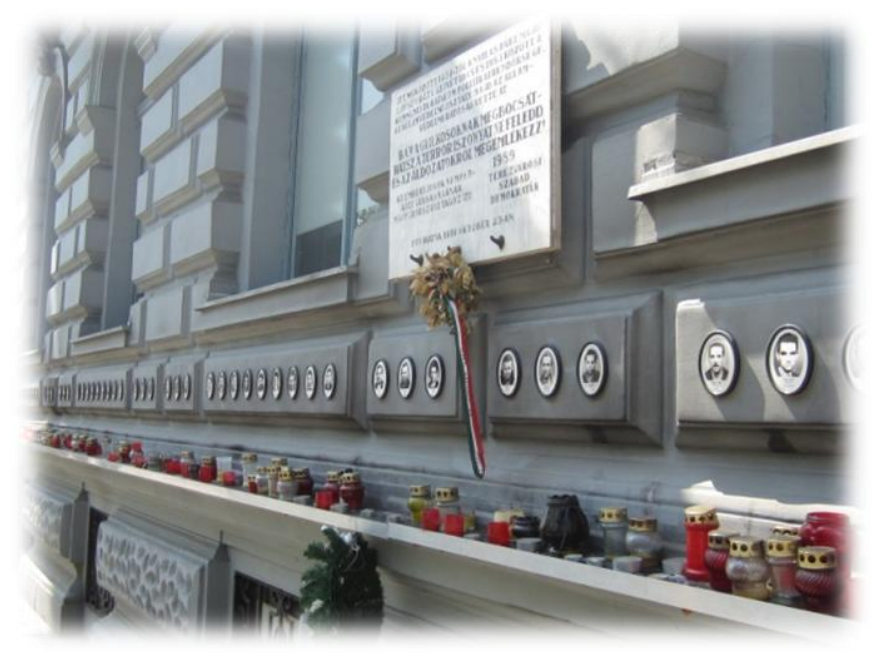

Figure 8. "House of Terror Museum, (Andrássy Street, Budapest)." Figure depicts the framed pictures adorned with candles and ribbons as a memorial to those who lost their lives under the Nazi and Communist regimes. Image credit: Alexandra Coffman

The choice to use the term "House" instead of "Museum" can show the audience many things. Perhaps it means that the design team felt that its narrative was an alternative one, or that its members wanted to focus on certain aspects of Hungarian history more than others. In the publication Entering the Minefields: the Creation of New History Museums in Europe, Gaal and Dupont write that there has developed a fear of the term "museum" which comes from the lack of awareness of what a modern museum is. ${ }^{137}$ In Hungarian, the term "Haza" can be translated in many ways, including "home" and "mother country," which has strong patriotic connotations. ${ }^{138}$ Whether the choice for the name reflects Hungarian patriotism or desire to express its non-traditional narrative, the House of Terror is a large museum depicting the victimization of Hungarians in the $20^{\text {th }}$ century.

\footnotetext{
137 Taja Vovk van Gaal and Christine Dupoint, "The House of European History" in Entering the Minefields: the Creation of New History Museums in Europe, 50.

138 "Haza," Sztaki Szótár Hungarian-English Dictionary, accessed March 20,2013, http://szotar.sztaki.hu/en/hungarian-english-

dictionary/search?fromlang=hun\&tolang=eng\&searchWord=haza\&langcode=en\&u=0\&langprefix=en\%2F\&searchMod e=CONTENT_EXACT\&viewMode=full\&ignoreAccents=0\&dict\%5B\%5D=hun-eng-sztaki-dict.
} 
The museum exhibits are arranged in chronological order, starting with the Nazi/Fascist era. The visitor is bombarded with startling music, intense lights, and details about the Nazi/Fascist regime. Although the museum is dedicated to the terror of both regimes, it is mainly focused on the communist years, understandably because this period was decades-long. In her thesis, Morales writes

...that because of the methods of "putting visitors into 'a historic situation'...the museum has garnered mixed reactions to its exhibits. On the one hand, its efforts are supported by strong ticket sales and a reputation as Hungary's most successful museum... On the other hand, the museum has also been openly critiqued for its choice of interpretive and narrative frameworks that meld the National Socialist and Soviet Socialist era in Hungary. ${ }^{139}$

The House of Terror works to put the visitor in the moment of history, and so most of the rooms are meant to impress upon the visitor the fear and oppression of the regimes. Many of the rooms are shocking to the senses, either by dramatic music, dim lighting, unusual room shape, or simply items displayed. The visitor starts on the top floor of the museum and makes her way down to the basement. The ride from the first floor to the basement is a very slow journey as an interview plays with a worker talking about the process of how criminals were prepared for hangings. Once in the basement the visitor can wander through tiny, windowless cells where prisoners were kept.

\footnotetext{
${ }^{139}$ Zulma-Lin Garcia Morales, “Cold War, Hot Topic: Museum Representations of 'Communism' in Post-Socialist Central and Eastern Europe," (MA thesis, University of Washington, 2012), 36, accessed February 23, 2013, http://search.proquest.com.www.libproxy.wvu.edu/docview/1034594192.
} 


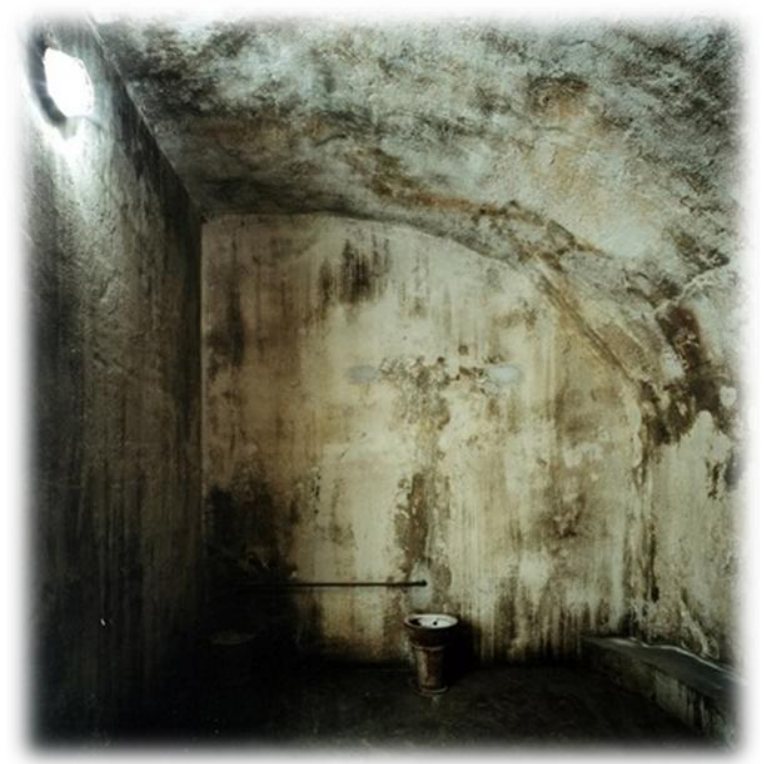

Figure 9. Cell in the basement of House of Terror Museum. These original cells are open for the public to view the harsh conditions prisoners endured.

Image credit: House of Terror museum

House of Terror Website

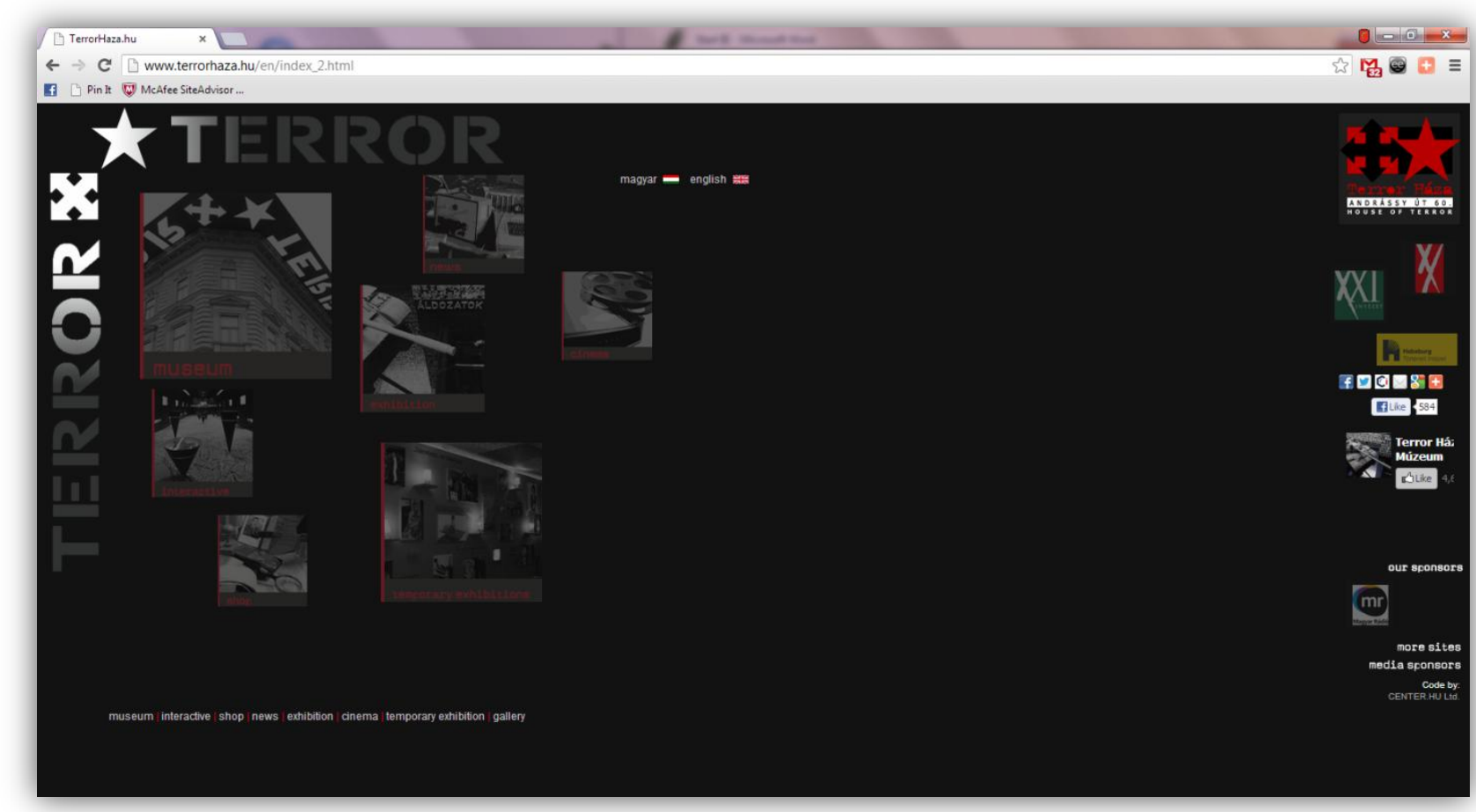

Figure 10. Screenshot of the webpage for the House of Terror Museum. [English]. Accessed February 13, 2013. http://www.terrorhaza.hu/en/index_2.html. 
The first view the House of Terror website is not very impressive. As one may notice, the page is not formatted to fit the entire screen, leaving unprofessional blank space on the right side of the screen. The poorly highlighted icons make it difficult for the visitor to read the categories that are randomly placed on the page. The language selection, however, is easy to locate.

The link titled "interactive" offers only a few interactive items: a guestbook, the opportunity to send a virtual postcard, and links to other sites. Some of the links are useful for those trying to continue research on the topic of the Nazi or Communist regimes. Helpful links include the Czech National Museum, Deutsches Museum, The Holocaust Centre, and Yad Vashem. Other links are too vague--a link to the general Smithsonian page does not help an amateur researcher. Some are incorrect links, such as the link to the Auschwitz Memorial Museum. Some are too out-of-date to be useful, such as the link to the conference on "Museums and the Web, 2003." Lastly, some have no obvious connection to Hungarian, Fascist, or Communist history, such as the link to "Artcylopedia." Many of these links were most certainly placed here to fill space and not to assist someone interested in learning more about these topics.

The page has a news site and an empty events page. It offers a layout of the museum, but only as a blueprint view and not as an informative map for visitors. The site includes a shop where a visitor can buy a candle version of a Stalin bust or a selection of books about the topics addressed in the museum. The English is excellent on the page and offers all the pages in Hungarian and English. The site is designed for all generations. The layout is simple, but designed to look "cool." Visitors of all ages should be able to use the resources provided. 
The photo galleries of the museum, as well as their temporary exhibitions, are comprehensive and of high quality. They allow visitors to get a sense of what they will be seeing or to look back on their visit. In addition to the photo gallery, the website offers an extensive video gallery that includes interviews, speeches, old films, conference recordings, and even the space to stream live broadcasts. This is a great resource for Hungarian speakers; however there are no sub-titles or text descriptions of the video clips for the non-natives who would visit this page. Still, these videos are a great research tool and primary source.

This website could be compared to the Budapest History Museum site (http://www.btm.hu/old/__english/fooldal/front.htm). The Budapest History Museum site provides much of the same information about the museum, basic pictures of displays, and some related news, although it lacks personal stories, like those contained in the Museum of Terror interviews. Both sites generally inform but do not actively engage their web audiences.

\section{Memento Park Open Air Museum, Budapest (suburbs)}

Communism certainly was a form of rule with a strong visual presence, bringing about the construction of thousands of statues and busts of leaders and socialist heroes throughout the Soviet bloc. These statues and monuments were built as grand and outstanding icons that were intended to "galvanize and inspire the masses." ${ }^{140}$ The change of political climate also called for a change of scenery as the towering statues were oftentimes brought down. Countries and more specifically cities, dealt with the

\footnotetext{
${ }^{140}$ Beverly James, "Fencing in the Past: Budapest's Statue Park," Media, Culture, \& Society 21 (1999): 291; accessed January 21, 2013, http://mcs.sagepub.com.www.libproxy.wvu.edu/content/21/3/291.
} 
statues of the leaders differently. Some have been left standing to this day; for example, the large Lenin monument that adorns the re-named Freedom Square in Kharkiv, Ukraine. Other countries—such as Hungary—had statues toppling as early as 1956, when revolutionaries in Budapest downed a Stalin Monument as a sign of anti-Soviet resistance. Levinson writes that monuments "are efforts, in a way, to stop time."141 Statues and monuments are also a very visible and concrete object with which to show displeasure or rebellion by destroying or vandalizing them.

Budapest decided that the statues must come down, but they should not necessarily be destroyed. What to do? Make an outdoor museum! This is what the city of Budapest decided for their busts of Lenin, statues of Soviet soldiers, and other socialist-inspired icons. Petrina Dacres writes, "images and public displays shape public discourse and memory... [they] are developed into symbols of cultural solidarity." ${ }^{142}$ The communist monuments' meaning changed as the political situation in Central and Eastern Europe changed. The statues of workers and leaders symbolized cultural solidarity, but when the communist regime was no longer, the statues only stood as a reminder of the unsavory past. Monuments can become "subject[s] of social displeasure that may be independent of the work itself." ${ }^{143}$ The social displeasure with the communist government was linked with the statues, and so the citizens of Budapest wanted them removed from their places of honor in the city center and placed somewhere else where they could be reinterpreted.

\footnotetext{
${ }^{141}$ Sanford Levinson, Written in Stone: Public Monuments in Changing Societies (Durham, N.C.: Duke University Press, 1998), 7.

${ }_{142}$ Petrina Dacres, "Monument and Meaning," Small Axe 8.2 (2004): 137.

143 lbid, 137.
} 
Memento Park is located in the suburbs of Budapest, far from the city centers of Buda and Pest, where the statues once stood. It was established in 1993 in the outskirts of the city. ${ }^{144}$ James writes that one could read this banishment of the statues into the suburbs as a symbolic "quarantine" of the past. ${ }^{145}$ Another way to interpret the statues behind the brick walls and wire fences is the imprisonment of those who once imprisoned the Hungarian people both within the Soviet Bloc and in prisons cells. ${ }^{146}$ One author even used the loaded phrase "a gulag for fallen idols" in describing the new location of these statues. ${ }^{147}$ The designer, Ákos Eleőd, writes that this park was not meant to be a place of irony but remembrance. ${ }^{148}$ Whether these statues are quarantined or imprisoned by the fences that are now surrounding them, they have been removed from everyday life and into a setting meant only to examine what once was and as a reminder not to let it happen again.

The mission of the park is to "to call forth the atmosphere of dictatorship, and to simultaneously provide the opportunity for this to be processed and critically analyzed." ${ }^{149}$ Tourism is obviously an important goal of this park, but it is also intended to preserve the history that these statues represent.

\footnotetext{
144 James, "Fencing in the Past," 292.

145 lbid, 303.

146 lbid, 303.

147 Sylvia Plachy, "Graveyard of the Statues: Communist Heroes, in Perspective," The New York Times Magazine, May 2 1993, accessed March 5, 2013,

http://find.galegroup.com/gic/infomark.do?\&source=gale\&idigest=8e9ba585464401187440005a9380bfe2\&prodld=Gl C\&userGroupName=morg77564\&tabID=T003\&docld=A174554141\&type=retrieve\&contentSet=IACDocuments\&version $=1.0$.

148 "Conception" Memento Park, accessed February 21, 2013, http://www.mementopark.hu/pages/conception/. 149 lbid.
} 


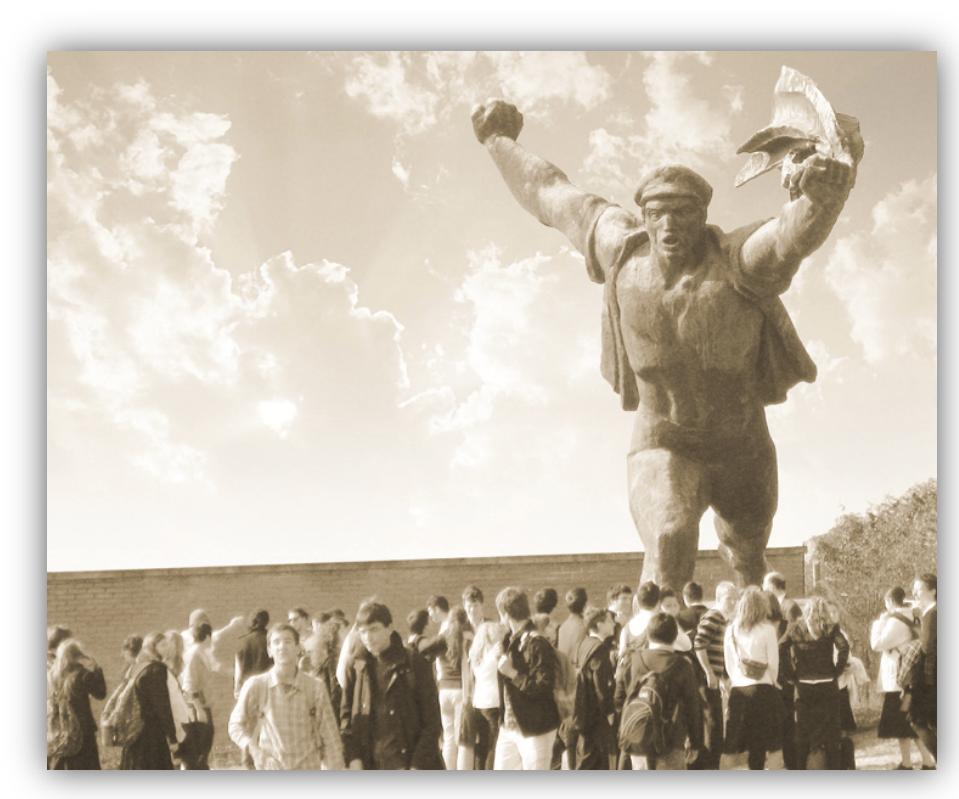

Figure 11. One of the many large communist statues moved to Memento Park open air museum. Image credit: Memento Park

It is easy to be skeptical about the value of a park full of old statues. These are statues that people do not want in the city, but do not want destroyed for the sake of historical memory. James writes that the public has questioned the museum's value and been skeptical about the project, but it has been a part of coming to terms with the past in its own, unique way by both removing the statues but keeping them in existence. ${ }^{150}$ The artist writes that Memento Park was built to be a tourist destination, an artistic action ground, and an educational centre. ${ }^{151}$ The Park offers educational tours with a museum pedagogy staff to assist students and their teachers, providing lesson plans, ideas and materials. ${ }^{152}$

James writes, "The Memento Park is not about Communism, but about the fall of Communism!"153 It was built to be an open interpretation of Hungary's communist past. Eleöd explains that he "deliberately minimized his own creative authority in order to

\footnotetext{
150 James, "Fencing in the Past," 293.

151 "Conception," Memento Park, accessed February 21, 2013, http://www.mementopark.hu/pages/conception/.

152 "Offers," Memento Park, accessed February 21, 2013, http://www.mementopark.hu/pages/offers/.

153 lbid.
} 
respect the diverse memories and experiences of the museum's visitors." ${ }^{154}$ Citizens and visitors alike have attached different associations, attachments, and meanings to these icons, and so the park/museum is set up more as a self-interpretation piece than a set narrative.

Movement and reinterpretation of monuments and historical symbols are not new. For example, in the book Memory in Black and White, Paul Shackle writes about the many moves and reinterpretations of the John Brown Fort in Harpers Ferry, West Virginia, USA. This fort was moved between black and white communities, between fairs and private owners, farms, and parks. The white and black communities differed on who should own the monument and who should visit it. Its meaning changed as the times and feelings toward slavery, civil rights, and other movements came about. Now resting in Harpers Ferry National Historical Park, Shackle writes that "the National Park Service interpreter leaves the visitor with the notion that determining the difference between civil disobedience and a criminal act can vary between people and groups and opinions may change through time." 155 This rings true for many historical symbols, especially those from a more recent past, which makes their interpretation that much more difficult for the historian.

It is difficult to say whether the removal and relocation of the statues was the proper move. On the one hand, starting with a clean slate requires the removal of things from the past. The looming statues served as a reminder of the forty years of communism that Hungary endured. In some cases, a statue was removed and another

\footnotetext{
154 James, "Fencing in the Past," 296.

155 Paul A. Shackel, Memory in Black and White: Race, Commemoration, and the Post-Bellum Landscape (New York: Alta Mira Press, 2003), 75.
} 
replaced it. For example, a worker statue was replaced with a cross to commemorate the church that was destroyed in order to construct a statue in the first place. ${ }^{156}$ James quotes Yampolsky on the double semiotics of iconoclasm in that "the act of destroying a monument and replacing it with a new one is a twofold symbol of victory. The new monument not only represents the ideals of the victors, it stands as a vestige of what is now absent." ${ }^{157}$ This double victory certainly feels gratifying immediately after a change of rule, but should one remove reminders of the past simply because they are uncomfortable or irritating?

Some citizens and former citizens of Budapest do have an attachment to these Communist statues. Plachy writes that she no longer recognizes the city of her childhood without the large statues looming over the streets; their removal also diminished her familiarity with the city and cityscape. ${ }^{158}$ James writes about a friend who had a statue near his house and would always meet friends at the "Futóbolond" (Running Fool) statue. ${ }^{159}$ Now, he writes, "to meet at the Running Fool" has no meaning. ${ }^{160}$ An article in The New York Times quotes a citizen saying, "We will miss [the worker statue], because the children used to climb all over it." ${ }^{161}$ The statues had already been ironically interpreted as part of coping with communism in the first place; the iconoclastic worker nicknaming "The Running Fool" and children using it as a jungle gym had already taken away from its relevance as a stoic and inspirational monument. Taking away these symbols, James writes, "goes beyond nostalgia to an awareness of

\footnotetext{
156 "Budapest Watches Statues Trundle In and Out of Exile," The New York Times, October 4,1992, accessed March 5, 2013, http://www.nytimes.com/1992/10/04/world/budapest-watches-statues-trundle-in-and-out-of-exile.html.

157 James, "Fencing in the Past," 293.

158 Plachy, "Graveyard of the Statues: Communist Heroes, in Perspective."

159 lbid, 307.

160 lbid, 307.

161 "Budapest Watches Statues Trundle."
} 
the always-present absence of an ironic discourse through which life under communism was interpreted." ${ }^{162}$ Symbols and monuments do not always need to be removed to lose their original meaning and in fact may even stand, to the citizens, for the opposite of their intended meaning.

The difference between bad statues and good statues simply depends on who is in charge and what time period it is. The New York Times article states that now "heroic workers and Soviet liberators are out; royalty and the Virgin Mary are in." ${ }^{163}$ The other issue with removing these statues is that, although they were Soviet-inspired, they were mostly fashioned by Hungarian artists. The sculptor of the Hungarian Soviet Republic monument, Ivan Kiss, said "1919 is as much a part of Hungarian history as any other period. ${ }^{164}$ Regardless of what the art is portraying, it was still the work of Hungarian artists and is part of the story of the nation. History is filled with conquerors coming into places and replacing one set of symbols with another; it simply depends on who holds political and cultural power as to which symbols are acceptable.

In A Sense of History, David Glassberg writes about a local World War I monument in Massachusetts. This monument was created by the community to express its personal interpretations of war. This can be related to Statue Park. Although communism and Soviet influence had a large reach across Central and Eastern Europe, each country or even city experienced it differently. Being able to reallocate the statues that were constructed for a distant ruler to a new location for reinterpretation and

\footnotetext{
162 James, "Fencing in the Past."

163 "Budapest Watches Statues Trundle."

164 lbid.
} 
tourism gives the community a chance to express its desire to move on from that part of history while still keeping it close as a reminder of the past.

Although the question of what to do with the communist statues in Budapest was not a vital issue, it came down to whether the statues were irritating enough to be removed. The Budapest city council came to the compromise of moving, but not destroying, these statues to a place where they could be interpreted as a commentary on the past. Thus, Memento or Statue Park was created to tell the story of Hungary's communist past, "to call forth the atmosphere of dictatorship, and to simultaneously provide the opportunity for this to be processed and critically analyzed." 165

\section{Memento Park Website}

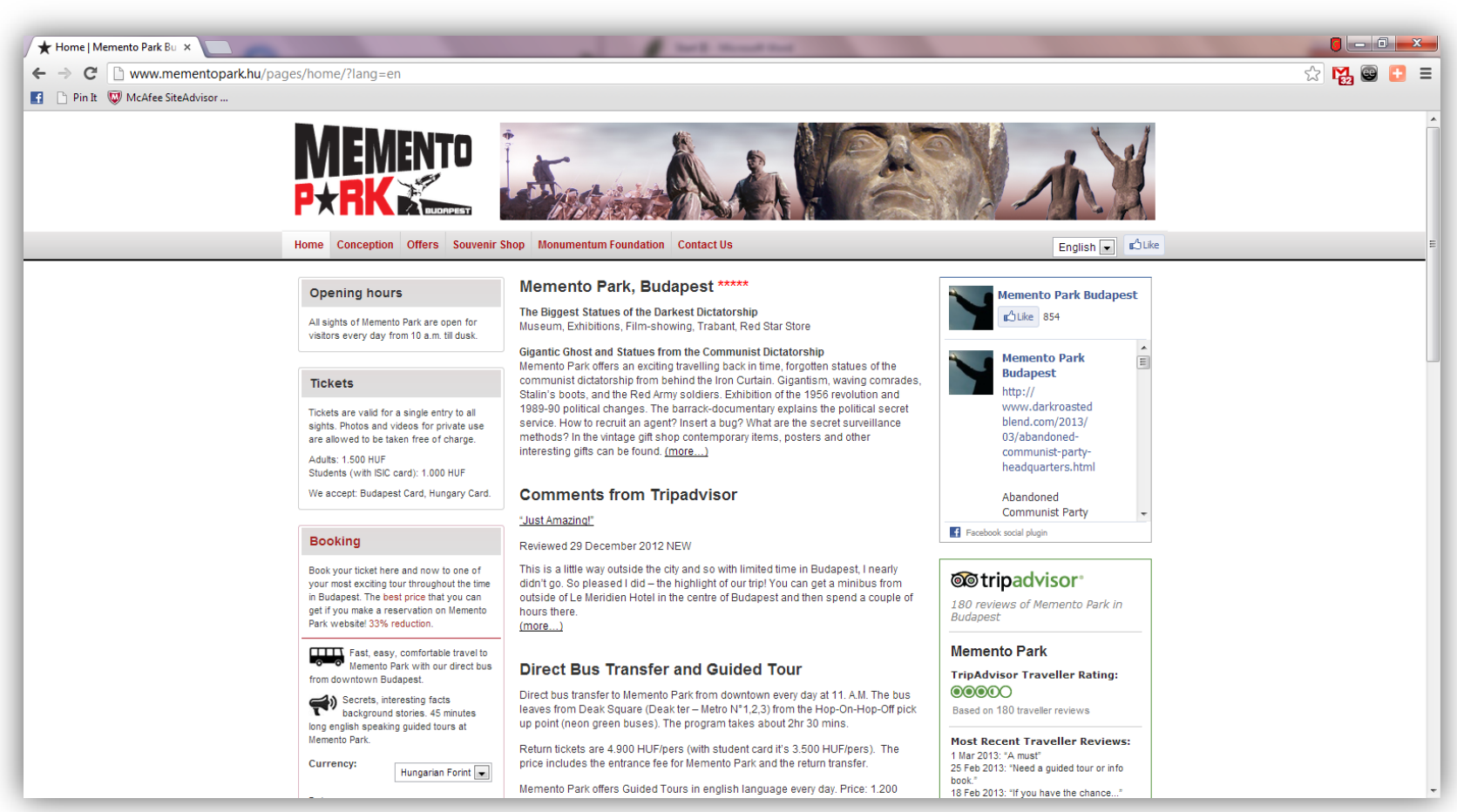

Figure 12. Screenshot of Memento Park webpage. [English]. Accessed February 21, 2013. http://www.mementopark.hu/pages/home/?lang=en.

\footnotetext{
165“Introduction,” Memento Park, accessed May 25, 2013. http://www.mementopark.hu/pages/conception/.
} 
The website for Memento Park is a well-laid out site that allows the visitor to easily access the pages in English and Hungarian. The most frequently needed information, such as ticket prices and operation hours, is displayed on the first page, along with a photo gallery of visitors and recent activity at the park. Social media websites are also easily accessible, showing that the park is active on more than one platform.

An "outdoor museum" or park full of old statues is a somewhat difficult concept to understand, so the website offers a multi-tabbed explanation of the "conception," including response, concept, historical background, commendation, architect, and introduction. "Response" includes responses about the idea of the park from prominent Hungarians such as the President, Minister of Culture, Head of the Tourism department, an art historian, and the chief architect of Budapest. ${ }^{166}$ The attention and comments by these prominent figures give credence to the park. The concept is explained on the next tab by the park designer, Ákos Eleöd. Here, he gives the themes, purpose, and ideas he had in designing this outdoor museum. He also writes about the commendation of his project. Ákos Eleőd's resumé is listed as well to show that he was a competent and well-qualified man for the job. His resumé includes a doctorate in Historic Monuments Engineering as well as numerous jobs dealing with Hungarian history. The "historic background" section gives a brief history of Hungary in the $20^{\text {th }}$ century for visitors to the park. The history is quite informative and written at a level that is readable by the common visitor but goes into enough detail for her to get a good grasp of the history of

166 “Conception," Memento Park, accessed February 21, 2013. http://www.mementopark.hu/pages/conception/. 
the country. Even to the historian's eye, it comes off as mostly unbiased and provides good background information for visitors. The introduction tab (which is oddly at the end of the list) gives more details about the park with some brief historical facts throughout. This section is more disorganized and could easily have been incorporated into the other sections.

The website has a large section on "offers" - discounts for seniors, students, groups, etc. This section does give information about the park's educational program. Memento Park offers museum pedagogy classes consisting of "lesson plans, excerpts from literature, tests and a workbook published by the park [to] aid the students in gaining insight." ${ }^{167}$ This educational program can help with the interpretation and narrative of an otherwise non-defined history of these statues and memorials. Also, true to the change from communism to capitalism, the outdoor museum is open for business events and parties. In keeping with the profit motive and to attract tourists, the website offers visitors many Soviet and communist-themed items from the "Red Star Store."168 For Hungarian visitors, the website lastly offers reports from the Monumentum Public Forum for the years 2007-2010. ${ }^{169}$

With the social media links in clear view as well as tips from TripAdvisor, this website was geared for the young to middle-aged traveler, although it is usable for all. The "Historical Background" does a sufficient job of informing any visitor who does not know about communism in Hungary or the statues in Memento Park.

\footnotetext{
167 "Offers," Memento Park, http://www.mementopark.hu/pages/offers/.

168 "Shop," Memento Park, http://www.mementopark.hu/shop/.

169 "Monumentum Foundation," Memento Park, http://www.mementopark.hu/pages/monumentum/.
} 
Not immediately noticeable are the links that line the bottom of the page. These lead the visitor to some questionable sites including a motor race across the country and a website to purchase a fake Soviet passport. While these are fun, they diminish the credibility of the museum site. These links also lead the visitor to other communist history museums around Europe. Overall this site is well done, but on closer inspection a visitor understands that this is not a highly academic museum, but more of a tourist destination.

\section{Conclusion}

Hungary, like Germany, has used a historical building to create a space of memorial. The Secret Police headquarters in Berlin was turned into a museum and used to educate about the secret workings of the Stasi. By renovating and repurposing the Secret Police headquarters in Budapest, the new, free society was able to take control and reinvent it as a memorial, thereby controlling the memory of communism and to show Hungarians as its victims. The same goes for the memory of the statues and monuments of Memento Park - by placing them in a contained area away from their original locations, it took away their intended meaning. Grouping statues together took away their individuality and repackaged them as all statues of the communist regime. The statue of Lenin once stood tall to encourage loyalty, devotion, and a strong regime; it now stands among dozens of other statues representing the ruins of communism and the power the nation now has over the communist leaders, be they real or stone. 
In the book The Unfinished Bombing, Edward Linenthal writes that the revitalization of downtown Oklahoma City also helped "the emotional rebuilding of the city." ${ }^{170}$ By cleansing Budapest of constant reminders of the oppressive past, it helped, or at least attempted to help, remove the difficult feelings of the past and place them out of sight and presumably out of mind. In Memento Park, their interpretation of the past can be confined to a particular space and only needs to be dealt with when one visits the park.

Hungary is not unique in keeping buildings or relics of the past and using them for profit and education. The remains of the Alamo were carted around and charged per view, pieces of the Berlin Wall were kept and sold, as were bricks from the Warsaw Ghetto and scraps from the USS Arizona. ${ }^{171}$ Hungary is finding the balance between moving on from the past while still remembering it.

170 Edward T. Linenthal, The Unfinished Bombing: Oklahoma City in American Memory (New York: Oxford Press, 2001), 53.

171 lbid, 142. 


\section{Chapter Six: Estonia}

Estonia, a small country with a population of only 1.3 million people ${ }^{172}$, also experienced intense occupations by the Nazis and the Soviets over the course of the $20^{\text {th }}$ century. After centuries of being under the rule of various states and empires, Estonia gained independence in 1918. In July 1940, Estonia was forcibly incorporated in the USSR after a result of false elections. ${ }^{173}$ A year later, in July of 1941 , the German occupation of Estonia began. ${ }^{174}$ However, in 1944, the Soviets re-conquered Estonia. ${ }^{175}$ The country remained under Soviet rule until it regained its freedom on August 20, 1991, after the collapse of the Soviet Union.

Estonia developed a unique form of nationalist resistance against the occupations as shown in their song festivals and Singing Revolution of 1988-1989. In 1938, they held a festival that celebrated their national pride and short independence. In 1947, another festival was held, and in spite of the Soviet wishes, it too was also a celebration of Estonian identity. The seed planted in this festival would "bear the fruit" in the 1988 Singing Revolution which helped lead to Estonia's independence in 1991. ${ }^{176}$

172 “Estonia," CIA World Fact Book, accessed March 11, 2013, https://www.cia.gov/library/publications/the-worldfactbook/geos/en.html.

${ }_{173}$ Jean-Jacques Subrenat ed., Estonia: Identity and Independence, trans. David Cousins, Eric Dickens, Alexander Harding, and Richard c. Waterhouse (Amsterdam: Rodopi, 2004), 137.

${ }_{174}$ Ibid, 307.

175 Ibid, 307.

${ }^{176}$ David Puderbaugh, "How Choral Music Saved a Nation," Choral Journal 49, no. 4 (October 2008):30, accessed March 12, 2013, http://ad4tq3gq5x.search.serialssolutions.com/?ctx_ver=Z39.882004\&ctx_enc=info\%3Aofi\%2Fenc\%3AUTF-

8\&rfr_id=info:sid/summon.serialssolutions.com\&rft_val_fmt=info:ofi/fmt:kev:mtx:journal\&rft.genre=article\&rft.atitle=Ho $\mathrm{W}+$ Choral+Music+Saved+a+Nation\%3A+The+1947 +Estonian+National+Song+Festival+and+the+Song+Festivals+of +Estonian\%27s+Soviet+Occupation\&rft.jtitle=The+Choral+Journal\&rft.au=David+Puderbaugh\&rft.date=2008-1001\&rft.issn=0009-5028\&rft.eissn $=2163-$

2170\&rft.volume=49\&rft.issue=4\&rft.spage=28\&rft.externalDBID=CHJL\&rft.externalDoclD=1598129921 . 
Estonia's historical narrative is thus focused on opposition to foreign occupation. The museum created to express this narrative was built in the capital city of Tallinn and entitled "The Museum of Occupations." "Occupations" is an important term which shows that Estonians do not feel like they were a part of these regimes, that other countries occupied their land and this museum is a record of those occupations. Estonia is unique in that it was annexed and incorporated into the Soviet Union, unlike the other countries discussed in this thesis that were only dominated by the USSR.

\section{Museum of Occupations, Tallinn}

The Museum of Occupations is located in Tallinn, Estonia. It was established to present the history of Estonia from 1940-1991, when it was alternatively occupied by the Soviet Union, Germany, and the Soviet Union once again. ${ }^{177}$ Although the occupations were rather long and intensive, the museum is small and consists of only two floors. It is a privately-run museum by the Kistler-Ritso Estonian Foundation.

The museum and its permanent exhibits opened in $2003 .{ }^{178} \mathrm{It}$ is easily accessible in the city. It is small but tells the story of the occupations in its limited space. The second floor is used as an open storage of large busts of Lenin and other miscellaneous statues and busts from the Soviet era.

177 “In General," Museum of Occupations, accessed March 1, 2013, http://www.okupatsioon.ee/english/.
178 lbid. 


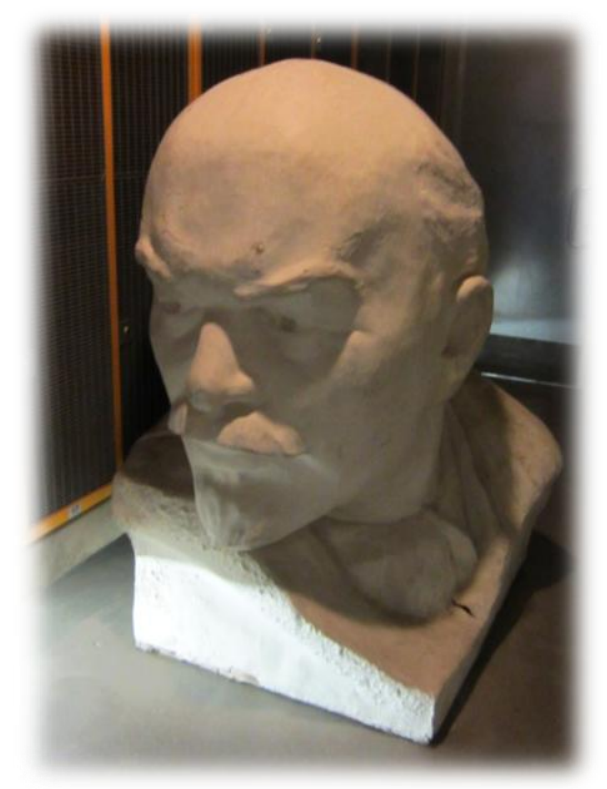

Figure 13. Bust of Lenin located in the lower floor of the Museum of Occupation in Tallinn, Estonia. Many busts and statues were left from Soviet times. Some, like this bust, were placed in the museums.

Image Credit: Alexandra Coffman

The Museum of Occupations was created for several reasons, including having a place to research and understand the past regimes, and to memorialize the victims of the occupations. In The Kistler-Ritso Estonian Foundation Goals and Objectives, it states that "The museum deals with a period about which we have incomplete information - an epoch characterized by totalitarian power and mass repression - and there is a plan to create a memorial complex, to remember those who did not return to their homeland. It would be a tombstone for the thousands of countrymen buried in anonymous graves. "Our dead will remain unburied until the memoirs [sic] of those that perished are immortalized." ${ }^{179}$ The mission is to memorialize and share the history of the Estonian citizens of the twentieth century.

Language is often a problem, especially in smaller countries with less-thancommon languages. Estonia and its museums are certainly an example of that. The museum is labeled in Estonian, and the visitor is provided with a translated guide-page

\footnotetext{
179 "Who We Are," Museum of Occupations, accessed March 1, 2013, http://www.okupatsioon.ee/english/.
} 
of the labels and displays in the museum. This shows the focus on Estonian citizens and a museum dedicated to their country's history. The displays are not bogged down with translations into several languages, but are provided on paper for visitors. This shows that the museum, along with the website, is focused on reaching a domestic audience first with a secondary focus on international tourism. With the emphasis on memorial and remembrance of an untold history, the museum is first and foremost for the native population.

\section{Museum of Occupations Website}

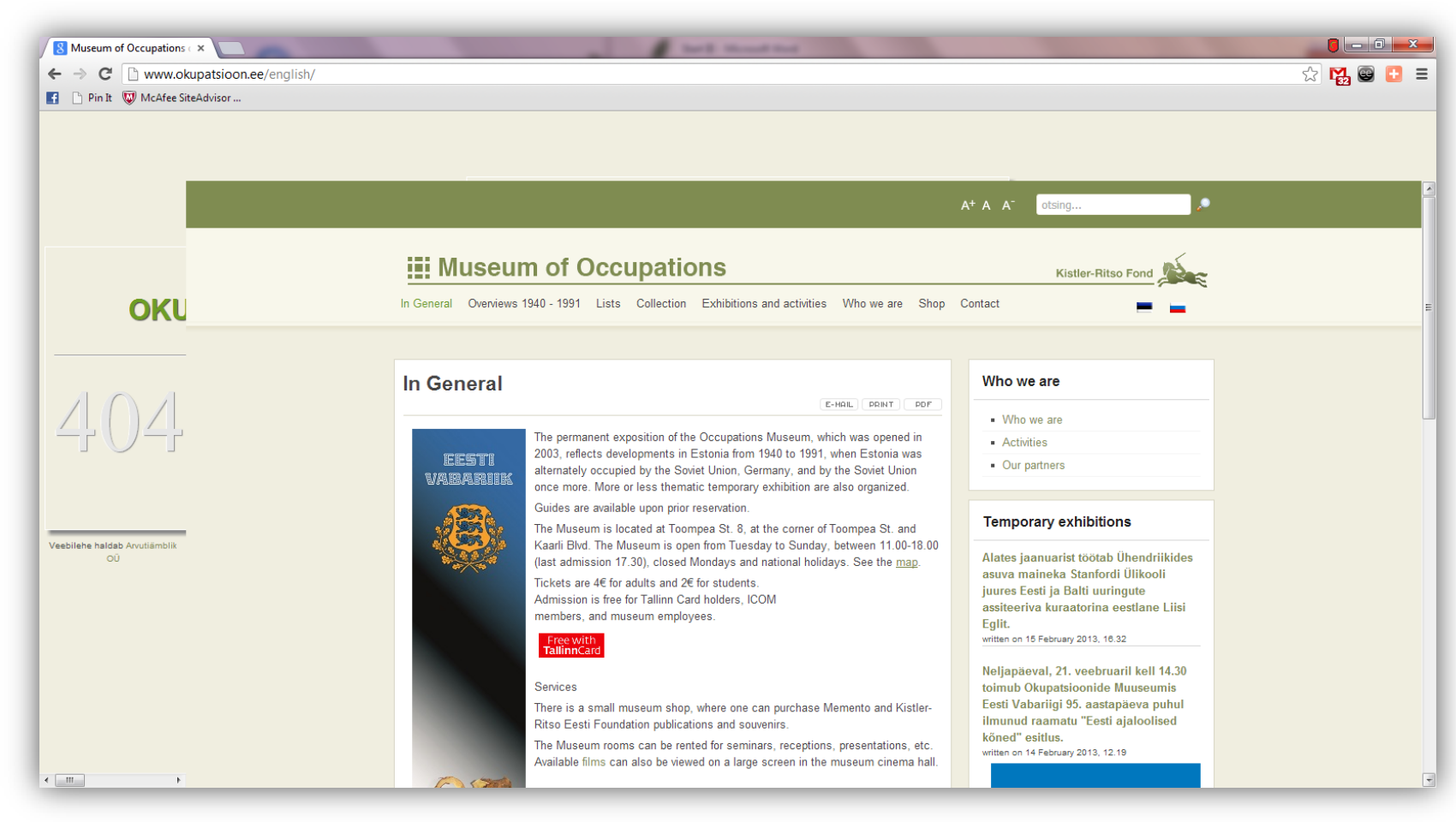

Figure 14. Screenshot of Museum of Occupations webpage. [English]. Accessed March 1, 2013. http://www.okupatsioon.ee/english/.

The website for the Museum of Occupations also makes an effort to tell its story in multiple languages. However, the entrance page does not have any English 
translations and the web visitor must randomly click an Estonian link to get to the language selections. Opening the main link to The Museum of Occupations serves the viewer with an error box, the title "Okupatsiooni Muuseum," and a list of categories in Estonian. ${ }^{180}$ This welcome screen certainly does not invite the amateur historian or even tourist to go further; however, after clicking on any Estonian category, the reader is led to a screen with the options of Russian or English translation. The English translation is good, but it only functions on some of the pages while other pages simply show the phrase "There are no translations available." ${ }^{181}$ Also, many side links remain in Estonian even when English is selected. There is a comprehensive translation of the site into Russian, showing the language influence of the former Soviet Union as well as suggesting that Russian-speaking web visitors are more likely to visit the site than English-speaking visitors. This is most likely due to the large Russian population still residing in Estonia.

The website states that its homepage "is part of a so-called virtual museum."182 However, the lack of interactive components shows it neither a virtual museum nor a very good website for conveying information about the museum in general. Simply having information online does not create a virtual museum, but rather an online form of flyers that businesses have posted for decades.

With reports of the Kistler-Ritso Estonian Foundation, even the erudite tone of the introduction shows that this website is geared toward highly-educated adults. There are no interactive parts and only minimal photos or other visual material. Apparently

\footnotetext{
180 "Okupatsiooni Muuseum," accessed March 1, 2013, http://www.okupatsioon.ee/english/.

181 "Collection," Museum of Occupations, accessed March 1, 2013, http://www.okupatsioon.ee/english/.

182 "Who We Are," Museum of Occupations, accessed March 1, 2013, http://www.okupatsioon.ee/english/.
} 
there is a history of 1940-1991 that gives the web visitor an overview of the recent history of Estonia. However, it is not translated to English, so it only serves to educate Estonian and Russian speakers.

The general tone about communism and the Soviet Union is a harsh one, as the museum is dedicated to occupation victims. In the "Occupation Period Overview," the topics include "destruction of the Estonian State," "Persecution of the People," and "Resistance." ${ }^{183}$ This museum is very concentrated on the outside forces and governments that have occupied the country. It is a period of history that Estonians do not really consider their own and they used the museum to expresses this. Its focus is on the occupiers, with little to no focus on Estonian collaborators. While it is important for outsiders to know this history, it is particularly important for Estonians to be able to express it in their own language and to the native Estonian population.

Overall, this website is not very useful to someone interested in general Estonian history, especially if the visitor does not read Estonian or Russian. While this shows the focus on the native population, the website in general is not particularly useful to visitors wanting to learn more than a brief history and the museum operation times.

\section{Conclusion}

As a small country on the border of Russia, Estonia was heavily affected by the Soviet occupation. A large number of Russians moved into the country after its forcible incorporation into the Soviet Union, changing the population dynamics. Once Estonia re-achieved independence, it was important that Estonians were allowed to express

\footnotetext{
183 "Estonia's Occupations Revisited," Museum of Occupations, accessed March 1, 2013, http://www.okupatsioon.ee/english/.
} 
their country's history in their own language. The Museum of Occupations could then show the struggles the Estonians dealt with during the multiple occupations and tell the stories about the regimes that took over their small land.

Estonia is somewhat known for its technological advances in "being wired," as home of the co-creator of Skype as well as making internet access a human right for its citizens. ${ }^{184}$ The mediocre website of the Museum of Occupations is not the product of the environment, but a reflection of the museum. It is a small, privately-run museum and perhaps the staff is not well-versed in web design, much like the Museum of Communism. However, this museum website could also be compared to the Estonian History Museum's website. The Estonian History Museum is a state-run institution. The Estonian History Museum website, although somewhat more professional, also lacks full text translation for its international visitors. The most noticeable difference is the online Digital Library which is "a publically available web environment where you can find image, audio and video files from exhibitions and events at the Estonian History Museum, as well as the museum's collections." 185 The lack of online resources of the Museum of Occupations, or even a well-functioning website, hinders the dissemination of information on the important topic of the Occupations. The deficient website may even discourage some visitors from visiting the physical location, defeating the purpose of the museum.

\footnotetext{
184 Colin Woodard, "Estonia, Where Being Wired Is A Human Right," Christian Science Monitor, July 1, 2003, accessed April 1, 2013, http://ad4tq3gq5x.search.serialssolutions.com/?ctx_ver=Z39.882004\&ctx_enc=info\%3Aofi\%2Fenc\%3AUTF8\&rfr_id=info:sid/summon.serialssolutions.com\&rft_val_fmt=info:ofi/fmt:kev:mtx:journal\&rft.genre=article\&rft.atitle=Est onia $\% 2 \mathrm{C}+$ where+being+wired+is+a+human+right+\%3B + In+a+once-

crumbling+former+Soviet+republic\%2C+even+the+farmers+have+broadband+Internet+access\&rft.jtitle=The+Christia $\mathrm{n}+$ Science+Monitor \&rft.au=Colin+Woodard\&rft.date $=2003-07-$

$01 \&$ rft.pub=The+Christian+Science+Monitor\&rft.issn=0882-7729\&rft.spage=07\&rft.externalDoclD=353247591 .

185 "Digiteek," Estonian History Museum, accessed April 1,2013, http://www.ajaloomuuseum.ee/en/digiteek.
} 


\section{Chapter Seven: Conclusion}

Museums of Communism are an important part of the transition in dealing with the immediate past. Countries spanning the eastern and central part of the European continent have been able to look back at what has happened and begin to commemorate parts of history that were pushed aside or not acknowledged. Whether state-run museums, private museums, or just temporary displays were created, the important point is that countries are reexamining their recent past and deciding how they want visitors and outsiders to see that past.

Some museums are focused on memory of the victims of the regime, thereby emphasizing the victimization and not the collaboration of the population. This can be seen specifically in the House of Terror Museum, but also to a lesser degree in the Museum of Occupations. Names like "House of the Terror" and the "Museum of Occupations" can influence how people see and think about the recent past. It is much easier to focus on the victimization than the collaboration, especially since this history is so recent and much of the population that experienced it is still living.

The missions of the museum differ. Some, such as the Stasi Museum, are there to serve as a reminder of overcoming an unpopular regime and transitioning into a democratic society capable of dealing with history candidly. Others' missions, such as the House of Terror or the Museum of Occupations, strive to memorialize the victims of the occupations their citizens suffered under in the twentieth century. The Czech Republic did not make prominent museums a priority and allowed a small, private museum to fill the tourist void. Poland did not see a museum as a priority, but did create 
the IPN in order to deal with the communist past through educational displays, online sites, archives, and publications.

Because this topic is so recent and there are still so many citizens who lived through some or all of the events that these museums cover, they are much more likely to have emotionally and patriotically driven displays than museums that focus on the more distant past. The use of the language describing the Soviet Union and communism shows how the countries perceive the recent past and how they accept (or reject) it. In an example about recent history in the United States, the controversial Enola Gay exhibit focused on victimization of Japanese civilians by the United States, thereby, in some opinions, making the US look guilty of war crimes while insulting the US servicemen who participated in dropping the bomb. In History Wars, Edward Linenthal writes,

Embedded in such fear of the power of historians' words to shake the confidence of Americans was a sense that the whole nation was now in need of a dose of patriotic therapy; that history's purpose must be to bolster the self-esteem of a country of increasingly needy and vulnerable citizens. ${ }^{186}$

Many times this is the general public's view of historians and history-that a country's historians must represent the good to serve its citizens. In many cases, overly favorable interpretations of national history are making up for years of real historical oppression, but it is also driven by a general desire to cast one's nation in a positive light.

These museums come in many different shapes and sizes; they are run by governments, cities, and even private citizens. They receive different amounts of funding and can thus only hire a corresponding amount of staff. Some of the museums

\footnotetext{
${ }^{186}$ Edward T. Linenthal, History Wars: The Enola Gay and Other battles for the American Past (New York: Metropolitan Books, 1996), 62.
} 
presented in this study have put a large emphasis on web design while others have created their websites to present only the basic information needed to locate the physical museum during hours of operation.

As is basically required of all businesses and organizations, these museums and groups offer their information on websites. These websites are a way for outreach, both to bring visitors and tourists into the museum, but also to disseminate their information to people who will never visit the physical sites. Some museums, such as the DDR Museum, make excellent use of their online/ new media tools featuring everything from a comprehensive artifact catalog to virtual exhibitions. These museums contribute greatly to international outreach as well as online education for everyone from the curious tourist to the public historian. Other museums struggle with basic web design that detracts from any information they have on the site. In addition to poor layout, many of these museums do not utilize the ability to use their educational material on the web. This not only applies for English users, but for native speakers as well. This limits the number of people museums can reach and make aware of the history of their institutions.

Even putting the complicated and interactive parts of websites aside, it is surprising that so many of the important and influential museums neglect their online presence. The physical structure may be the most important part, but establishing a good online presence not only helps to inform a wider audience, it also helps with visitor numbers too. Online media and an interactive web presence is the future of museums and historical education. A poorly utilized website discourages visitors and misses educational opportunities, especially among the young. 
Of these case studies, the DDR Museum is the most interactive, professional, and even attentive as it is the only museum which bothered to respond to personal emails. They offer access to their museum catalog and present educational links to visit that include a virtual museum display. Many of the other museums fall at the other end of the spectrum with limited translation, faulty links, and low-quality websites.

These websites can be seen as a metaphor for the transition from communism for these states. Some, such as Germany, are doing it excellently with relatively smooth transitions, keeping pace with global trends in information technology. Germany had a unique transition from a separated state into a united one, and critical, well-done research of the current past helps put history into the open so citizens and outsiders alike can move beyond the troubled past. Hungary showed that it was eager to memorialize the forgotten victims of what was perceived as a cruel regime that did not recognize its crimes and brutal treatment of the citizens.

Other museums struggle with the online concept and format. They have issues with everything from language to complete communist history education. How museums and online displays of history are treated show, in part, how a country is dealing with the past. The way in which a museum is presented to the casual tourist and the web visitor shows what the accepted points of view are in each country. The language employed to depict this time period of communism and the Soviet domination shows the emotions attached to the recent past. While some countries, such as Germany, present the DDR and communist past as something that happened and is now another part of German history, other countries such as Estonia portray it as an unwanted occupation that can now be talked about publicly. These perceptions mold the way history is told to the 
public, and to both native and foreign audiences. History is only as good as its presentation, so if the IPN presents Polish citizens only as martyrs, then that is what Poles and those that visit the IPN learn about the past.

Museums are a way to show a country's past and now, with new media, a museum can have a longer reach and more interactive dialogues about history. Some countries and museums have shown an eagerness and willingness to do so, while others are only interested in presenting a singular perspective to a limited audience. As the online interaction continues to be a larger and larger part of education, historians, museum curators, and other professionals who interact with and interpret history must embrace new media and use it as an additional, important resource in reaching the public. 


\section{Bibliography}

Primary

"A Wonderful Museum of Terror in Budapest." The New York Times. August 20, 2008. Accessed March 10, 2013. http://intransit.blogs.nytimes.com/2008/08/20/a-wonderfulmuseum-of-terror-in-budapest/.

"Budapest Watches Statues Trundle In and Out of Exile." The New York Times. October 4, 1992.Accessed March 5, 2013. http://www.nytimes.com/1992/10/04/world/budapestwatches-statues-trundle-in-and-out-of-exile.html.

"Years of Change: A Typical Diary from the Time of German Reunification." DDR Museum. Google Cultural Institutions. Accessed April 3, 2013. http://www.google.com/culturalinstitute/?hl=en-GB\#!exhibit:exhibitld=gQD0zxxl.

Alperstaedt, Melanie. E-mail message to author. February 12, 2013.

Bartoszewicz, Dariusz. "Muzeum Komunizmu do Lamusa? Władze rezugnują." Gazeta Wyborcza. August 10, 2011. Accessed March 23, 2013. http://wyborcza.pl/1,76842,10098597,Muzeum_Komunizmu_do_lamusa_Wladze_rezyg nuja.html.

DDR Museum. Accessed February 16, 2013. http://www.ddr-museum.de/en/.

Die Behörde des Bundesbeauftragten für die Stasi-Unterlagen.Accessed April 2, 2013. http://www.bstu.bund.de/DE/BundesbeauftragterUndBehoerde/_node.html.

Estonian History Museum. Accessed April 1, 2013. http://www.ajaloomuuseum.ee/en/.

European National Museums. Accessed March 18, 2013. http://www.eunamus.eu/.

European Solidarity Centre. Accessed March 27, 2013. http://www.ecs.gda.pl/.

Fuller, Thomas. "Stark History/ Some See a Student: Memory Becomes a Battleground in Budapest's House of Terror." The New York Times, August 2, 2002. Accessed April 4, 2013. http://www.nytimes.com/2002/08/02/news/02iht-budapest_ed3_.html.

Google Cultural Institute. Accessed April 3, 2013. http://www.google.com/culturalinstitute/about/.

House of Terror. Accessed February 13, 2013. http://www.terrorhaza.hu/en/index_2.html.

Jewish Museum of Prague. Accessed April 3, 2013. http://www.jewishmuseum.cz/aindex.php.

Marienfelde Refugee Center Museum. Accessed April 3, 2013. http://www.notaufnahmelagerberlin.de/en/.

Memento Park. Accessed February 21, 2013.

http://www.mementopark.hu/pages/home/?lang=en. 
Museum of Communism. Accessed February 2, 2013, http://www.muzeumkomunismu.cz/.

Museum of Occupations. Accessed March 1, 2013. http://www.okupatsioon.ee/english/.

Ośrodek Karta. Accessed April 3, 2013. http://www.pametnaroda.cz/institution/detail/id/25.

Roy Rosenzweig Center for History and New Media. Accessed April 2, 2013. http://chnm.gmu.edu/.

Stasimuseum Berlin. Accessed March 3, 2013. http://www.stasimuseum.de/en/enindex.htm

The Institute of National Remembrance. Accessed February 13, 2013. http://ipn.gov.pl/en.

Willoughby, lan. "Bagel King Opens Czech Republic's First Museum of Communism." Czech Radio 7, Radio Prague. December 27, 2001. Accessed March 7, 2013. http://www.radio.cz/en/article/12239.

Woodard, Colin. "Estonia, Where Being Wired Is A Human Right." Christian Science Monitor. July 1, 2003. Accessed April 1, 2013.

http://ad4tq3gq5x.search.serialssolutions.com/?ctx_ver=Z39.88-

2004\&ctx_enc=info\%3Aofi\%2Fenc\%3AUTF-

8\&rfr_id=info:sid/summon.serialssolutions.com\&rft_val_fmt=info:ofi/fmt:kev:mtx:journal\&r $\mathrm{ft}$.genre=article\&rft.atitle=Estonia\%2C+where+being +wired + +is + a + human+right+\%3B+In $+\mathrm{a}+$ once-

crumbling+former+Soviet+republic\%2C+even+the+farmers+have+broadband+Internet+ access\&rft.jtitle=The+Christian+Science+Monitor\&rft.au=Colin+Woodard\&rft.date=200307-01\&rft.pub=The+Christian+Science+Monitor\&rft.issn $=0882-$

7729\&rft.spage $=07$ \&rft.externalDoclD=353247591

Secondary

"Estonia." CIA World Fact book. Accessed March 11, 2013. https://www.cia.gov/library/publications/the-world-factbook/geos/en.html.

"Haza." Sztaki Szótár Hungarian-English Dictionary. Accessed March 20, 2013. http://szotar.sztaki.hu/en/hungarian-englishdictionary/search?fromlang=hun\&tolang=eng\&searchWord=haza\&langcode=en\&u=0\&la ngprefix $=$ en\%2F\&searchMode=CONTENT_EXACT \&viewMode=full\&ignoreAccents=0\&d ict\%5B\%5D=hun-eng-sztaki-dict.

Andrews, Molly. "One Hundred Miles of Lives: The Stasi Files as a People's History of East Germany." Oral History 26 (1: Talking and Writing) (Spring 1998). Accessed February 4, 2013. http://www.jstor.org/stable/40179468.

Axelsson Bodil, Christine Dupont, and Chantal Kesteloot, eds. "Entering Two Minefields: Research for Policy-Making and the Creation of New History Museums in Europe." Conference Proceedings from EuNaMus, European National Museums: Identity Politics, the Uses of the Past, and the European Citizen. Brussels, 25 January 2012. EuNaMus 
Report No. 9, Linköping University Electronic Press. http://www.ep.liu.se/ecp/083/ecp12083.pdf.

Curry, Jane Leftwich and Luba Fajfer, eds. Poland's Permanent Revolution: People vs. Elites 1956 to the Present. Washington, DC: The American University Press, 1996.

Dacres, Petrina. "Monument and Meaning." Small Axe 8.2 (2004): 137-153.

Drakulić, Slavenka. A Guided Tour Through the Museum of Communism. New York: Penguin, 2011.

Dueck, Cheryl. "The Humanization of the Stasi in Das Leben der Anderen."German Studies Review (Oct. 2009). Accessed April 10, 2012. http://www.jstor.org.www.libproxy.wvu.edu/stable/27668596.

Garton Ash, Timothy. The File: A Personal History. New York: Vintage Books, 1998.

Gauck, Joachim, and Martin Fry. "Dealing With a Stasi Past." Daedalus 123 (1: Germany in Transition) (Winter 1994). Accessed November 18, 2012. http://www.jstor.org.www.libproxy.wvu.edu/stable/20027230.

Gehler, Michael. Three Germanies: West Germany, East Germany, and The Berlin Republic. Translated by Anthony Mathews. London: Reaktion Books, 2011.

Gribbin, Alice. "A Brief History of the Internet," New Statesman. Aug 15, 2011. Accessed March 3, 2013. http://search.proquest.com/docview/920812193?accountid=2837.

James, Beverly. "Fencing in the Past: Budapest's Statue Park." Media, Culture, \& Society 21 (1999). Accessed January 21, 2013. http://mcs.sagepub.com.www.libproxy.wvu.edu/content/21/3/291.

Kontler, László. A History of Hungary: Millennium in Central Europe. New York: Palgrave Macmillian, 2002.

Kopanja, Jelena. "Forty Years After Prague Spring, All That's Left of Communism is a Babushka with an Overbite." NYU Livewire. Accessed March 30, 2013. http://journalism.nyu.edu/publishing/archives/livewire/archived/forty_years_aft/.

Krosnar, Katka. "A Tribute to Barren Shops." Newsweek. February 10, 2002. Accessed March 20, 2013. http://www.muzeumkomunismu.cz/articles/newsweek.htm.

Levinson, Sanford. Written in Stone: Public Monuments in Changing Societies. Durham, N.C.: Duke University Press, 1998.

Linenthal, Edward T. History Wars: The Enola Gay and Other battles for the American Past. New York: Metropolitan Books, 1996.

Linenthal, Edward T. Preserving Memory: The Struggle to Create America's Holocaust Museum. New York: Viking, 1995. 
Linenthal, Edward T. The Unfinished Bombing: Oklahoma City in American Memory. New York: Oxford Press, 2001.

Machcewicz, Paweł. "Poland's Way of Coming to Terms with the Legacy of Communism." The Institute for Political Studies. Eurhistxx. Accessed April 20, 2012.

http://www.eurhistxx.de/spip.php\%3Farticle40\&lang=en.html.

Molnár, Miklós. A Concise History of Hungary. Translated by Anna Magyar. Cambridge: Cambridge University Press, 2001.

Morales, Zulma-Lin Garcia. “Cold War, Hot Topic: Museum Representations of 'Communism' in Post-Socialist Central and Eastern Europe." MA thesis, University of Washington, 2012. Accessed February 23, 2013, http://search.proquest.com.www.libproxy.wvu.edu/docview/1034594192.

Müller, Klaus. "Speaking English: A Dialogue with Eastern and Central European Museum Professionals." Curator: The Museum Journal. 48 (January 2005):1. Accessed April 1, 2013. http://ad4tq3gq5x.search.serialssolutions.com/?ctx_ver=Z39.882004\&ctx_enc=info\%3Aofi\%2Fenc\%3AUTF-

8\&rfr_id=info:sid/summon.serialssolutions.com\&rft_val_fmt=info:ofi/fmt:kev:mtx:journal\&r ft.genre=article\&rft.atitle=\%E2\%80\%9CSpeaking+English\%E2\%80\%9D\%3A+A+Dialogu e+with+Eastern+and+Central+European+Museum+Professionals\&rft.jtitle=Curator\%3A+ The+Museum+Journal\&rft.au=M\%C3\%BCller\%2C+Klaus\&rft.date=2005-01-

$01 \&$ rft.issn $=0011-3069 \&$ rft.eissn $=2151$ -

6952\&rft.volume=48\&rft.issue $=1 \&$ rft.spage $=57 \&$ rft.epage $=73 \&$ rft_id=info $:$ doi $/ 10.1111 \% 2$ Fj.2151-

6952.2005.tb00154.x\&rft.externalDBID=n\%2Fa\&rft.externalDocID=10_1111_j_2151_69 52_2005_tb00154_x

Paczkowski, Andrzej. The Spring Will Be Ours: Poland and the Poles from Occupation to Freedom. Translated by Jane Cave. University Park: The Pennsylvania State University Press, 1998.

Plachy, Sylvia. "Graveyard of the Statues: Communist Heroes, in Perspective." The New York Times Magazine. May 2 1993. Accessed March 5, 2013.

http://find.galegroup.com/gic/infomark.do?\&source=gale\&idigest=8e9ba5854644011874 40005a9380bfe2\&prodld=GIC\&userGroupName=morg77564\&tabID=T003\&docld=A174 $554141 \&$ type $=$ retrieve \&contentSet=IAC-Documents\&version=1.0.

Puderbaugh, David. "How Choral Music Saved a Nation." Choral Journal 49, no. 4 (October 2008). Accessed March 12, 2013, http://ad4tq3gq5x.search.serialssolutions.com/?ctx_ver=Z39.882004\&ctx_enc=info\%3Aofi\%2Fenc\%3AUTF-

8\&rfr_id=info:sid/summon.serialssolutions.com\&rft_val_fmt=info:ofi/fmt:kev:mtx:journal\&r ft.genre=article\&rft.atitle=How+Choral+Music+Saved $+a+N a t i o n \% 3 A+T h e+1947+$ Estonia $\mathrm{n}+\mathrm{National}+$ Song+Festival+and+the+Song+Festivals+of+Estonian\%27s+Soviet+Occupa tion\&rft.jtitle=The+Choral+Journal\&rft.au=David+Puderbaugh\&rft.date=2008-10$01 \& r f t$.issn $=0009-5028 \&$ rft.eissn $=2163$ 2170\&rft.volume $=49 \&$ rft.issue $=4 \&$ rtt.spage $=28 \&$ rft.externalDBID $=$ CHJL\&rft.externalDocl $\mathrm{D}=1598129921$. 
Scribner, Charity. Requiem for Communism. Cambridge: MIT Press, 2003.

Shackel, Paul A. Memory in Black and White: Race, Commemoration, and the Post-Bellum Landscape. New York: Alta Mira Press, 2003.

Starn, Randolph. "A Historian's Brief Guide to New Museum Studies." The American Historical Review, 110 (February 2005).

Stola, Dariusz. "Poland's Institute of National Remembrance: A Ministry of Memory?" In The Convolutions of Historical Politics, edited by A. Miller and M. Lipman, 45-58. Budapest: Central European University Press, 2012.

Subrenat, Jean-Jacques ed. Estonia: Identity and Independence. Translated by David Cousins, Eric Dickens, Alexander Harding, and Richard c. Waterhouse. Amsterdam: Rodopi, 2004. 